INVEST Working Papers 42/2022

\title{
Generational differences in income trajectories in the Nordic welfare state
}

Esa Karonen

Hannu Lehti

Jani Erola

Susan Kuivalainen

Pasi Moisio

5.1 .2022

ISSN 2737-0534 
The Inequalities, Interventions, and New Welfare State (INVEST) aims at increasing wellbeing of Finnish society during childhood, youth and early adulthood and preventing psychosocial risks compromising such development through innovative interventions. Based on cutting-edge research on the conditions and mechanisms involved at different periods of development, INVEST will evaluate and develop various universal and targeted interventions to improve the efficiency of the current welfare state institutions at critical points of the early life course. INVEST aims at providing a new model for the welfare states that is more equal, better targeted to problem groups, more anticipatory as well as economically and socially sustainable. INVEST is a Flagship project of the Academy of Finland. 


\title{
Generational differences in income trajectories in the Nordic
}

\section{welfare state}

\begin{abstract}
How much it matters for your income development what generation you happen to be born? We answer this question by using registers of the total population, we study generational income inequality during 1970-2018 and, for men and women in Finland. We follow the income trajectories of the cohorts born in 1920-1983 over their adult life course and observed, how certain structural factors explain differences in income trajectories. Our study expands state-ofthe-art knowledge, as previous research has often bypassed the question of how much generational income differences explains of populations total income inequalities and what factors may explain the different generational income trajectories. Results show that overall generational income differences explained quarter for women and 6 percent for men total income inequality. Each successive cohort until 1980s had a higher average income trajectory. However, generation born in the 1980s has been falling behind. For both men and women, age structure and education were the most important factors associated with income inequality. On contrary to previous findings on Nordic welfare state, our results also indicate that, generational income trajectories are affected by economic shocks.
\end{abstract}

\section{Introduction}

Stratification research has often bypassed the question of between-generation inequality under the assumption that the future generation will always have better living standards. However, if the assumption no longer holds, the question of inequality between generations becomes much more important for income inequality between individuals (Atkinson, 2015). Depending on the period, 
generations develop cohort-specific earning opportunities during their life course (Mannheim, 1928). Cohorts could begin their working life at a time of economic upturn, and they may monopolize profitable opportunities to follow the path of higher lifetime earnings. In contrast, some generations have to establish careers during economic downturns. Scholars have thus considered systematic cycles of "lucky" and "less lucky" generations (Chauvel and Schroder, 2014; Myles, 2002).

Society's institutions can compensate these consequences, but if not, the lower income accumulation for generations that face economic recession could pose a problem for the future. More than generational fairness, the issue also has the factor of how the current and future generations would finance public spending (Batini et al., 2011). Lower public spending may lead to unequal situations between generations, with succeeding generations becoming unable to enjoy publicly financed benefits, such as education or health care.

In the present work, we studied generational income inequality in the Nordic welfare state of Finland. We followed the income trajectories of the cohorts born in 1920-1983 over their adult life course in the period 1970-2018. We investigated how different social and demographic factors contributed to the income inequality between generations and individuals. When studying these generational differences in income trajectories, Mayer $(2000,2009)$ suggested that focus should be on mechanisms associated with inequalities across generations. Different demographic, social, and economic structures can affect the income development of generations. These mechanisms have been the black boxes of stratification research, as how cohorts income trajectories differ remains mostly unknown (Mayer 2009).

In some countries, younger birth cohorts have been left behind in terms of income development compared with older birth cohorts. For example, younger generations' prospects of earning more 
than their older counterparts have faded over the past half-century in the US, and this change is driven by unequal distribution rather than by changes in GDP growth rates (Chetty et al., 2017). Similar notions have been found in Europe (Berloffa and Villa 2010; Chetty et. al. 2017; Crawford et al., 2016; Karonen and Niemelä, 2020).

However, in countries where individuals' income inequality is lower, generational income inequality may also be lower. The institutional context of these countries may be the key factor that wields influence not only on individuals' income inequality but also generational income inequality. For example, liberal welfare regimes without strong social benefit systems seem to aggravate the consequences for income development among cohorts entering labor markets at a time of recession (Chauvel and Schroder, 2014). The observed differences between generations could be explained by institutional settings, such as income redistribution.

Although research has identified the disparity between generations, it has not clarified the factors associated with the cohort differences. Certain demographic and social factors that have changed over time and between generations may explain at least some part of the generational income inequality. For example, in recent decades, education has expanded rapidly and younger generations spend more years in higher education in their early adulthood compared the older ones (Härkönen and Sirniö, 2020; Lehti and Karonen 2020). Meanwhile, fertility has decreased and younger cohorts have fewer children (Jalovaara et al., 2019). People also live longer and the proportion of older people in the population has increased drastically. Further, different cohorts are facing different occupational structures and social benefit systems that can influence their income trajectories.

Research has not followed the income trajectories of individuals from different birth cohorts. Thus, our study aimed to show for the first time how income varies between cohorts by age. We used 
high-quality registers of the Finnish total population, following the cohorts born in 1920-1983 over their adult life course in the period 1970-2018. Previous studies have also used household income to measure income inequalities, whereas we used individual income. We are interested in the birth-cohort intra-class correlation (ICC) that can be considered a measurement of generational income inequality. By decomposing cohort variance, drawn from a series of random-effect models, we tested the role of five different factors that potentially contribute to generational inequalities: socioeconomic changes in the educational and occupational composition of society, employment, family, demographic changes, and social transfer as part of total incomes.

\section{Generational perspective on income development}

Role of policy and age structure in income accumulation

A generation carries unique experiences; different birth cohorts grow up in a similar historical period (Mannheim, 1928). In other words, important changes linked to income accumulation can occur over time, which can have different outcomes for each cohort group, as these outcomes are dependent on age and the overall characteristics of the cohort. For example, cohort groups have different educational opportunities, labor market composition, age structure, and social insurance schemes that vary over time.

Multiple important changes have occurred in the economy that have had a direct impact on the income accumulation of the different generations. These are changes in both socioeconomic and demographic composition. Thus, the question of "structure and policy" is relevant, given the interconnected issues of the aging population, smaller household sizes, and changing redistributive system of income.

Most developed countries redistribute income through public transfers and taxes; these institutions form the core of modern welfare (Esping-Andersen, 1990; Iversen and Soskice, 2009). Social 
insurance institutions are of central importance for redistributive outcomes (Korpi and Palme, 1998). The importance of social security benefits is different for each age and cohort group. The social security system was more modest before than today, and as such, the significance of the transfers of income in the welfare state for different cohort groups remains unclear (Kangas and Ritakallio, 2007; Kangas and Palme, 2000). In addition, societies face the steep future cost of aging populations with the increasing transfer costs (Freund and Smeeding, 2010).

Labor market opportunities and income distribution are related to demographic processes; in most industrialized countries, economic growth has slowed during the past decade. The post-WWII baby boom has been followed by a rapid decline in birth rates and mortality rates, leading to an increase in the aging population. The phenomenon has led to large changes in the age structure and differences between birth cohort sizes. Reductions in cohort size allow people to secure higher occupational and class positions, whereas a larger cohort size diminishes this advantage (Mugiyama and Toyonaga, 2021). Thus, larger cohorts can expect lower earnings on entry into the labor market, as competition increases if other factors are held constant. Human capital obtained through work experience is substantial at young ages but aging per se also accounts for a significant proportion of income growth.

Family size can have implications on generational income differences. European fertility rates have been declining at the cohort level (Myrskylä et al., 2013). These trends are often attributed to a combination of a slowdown in the postponement of births (Bongaarts and Sobotka, 2012) and increasing levels of socioeconomic development (Myrskylä et al., 2009) and per capita income (Thévenon and Luci, 2010). In Nordic countries, cohort fertility fell for the 1940s cohorts, then recovered somewhat for the 1950s cohorts, and then underwent a weak downward trend (Jalovaara et al., 2019). 
Among women, the presence of young children leads to lower involvement in the paid labor market and lower relative earnings (Budig et al., 2012). For mothers, childbirth implies some time away from paid labor. They return to work, often part-time, as the youngest child gets older (Budig et al., 2012). The reduction in earnings owing to motherhood has been found to depend on features of the labor market and social policy, which vary between generations (Gangl and Ziefle, 2009).

\section{Impact of social class and education on income}

Education is positively associated with higher social class and income trajectories (Breen et al., 2010). The opportunity to access educational opportunities vary between different generations but, overall, people's education levels have increased in all Western countries (OECD, 2019). Human capital theory (Becker, 1962; Mincer, 1970) assumes that variance in labor market earnings is connected skills and abilities attained from education. It has been shown to have a positive effect on income globally (Becker, 2009; Harmon et al., 2001; OECD, 2019). However, changes in the level of education could increase so-called "credential inflation"-_decreasing returns to education between generations - as the expansion of education could create an overabundance of highskilled people in the labor market, if the demand for high-skilled labor does not respond to the educational expansion (Halaby, 1994; Van de Werfhorst, and Andersen, 2005). According to Schofer and Meyer (2005), the rate of enrollment in higher education has increased globally by more than $200 \%$ over the past century. With the advancing educational expansion, credentialism can lead to the situation where the younger generations must compete with an ever-growing pool of educated individuals for the same jobs (Bol, 2015).

Occupational position is related to status attainment and human capital theory. In a sociological context, this position is defined by the class position that the individual occupies and the class in which the individual was raised. One definition is the Goldthorpe schema that captures the 
individual's differentiation in labor markets, which is important for the distribution of opportunities, jobs, or occupations (Erikson and Goldthorpe, 2002).

Studies on social mobility have found a convergent trend among European countries in their absolute mobility rates and class structures (Breen et al., 2010; Breen, 2018). For example, societies are seeing a decline in farming occupations and an increase at the top of the class structure in the service classes. Most of the changes occurred in the 1970s and 1980s (Breen et al., 2009).

Education and occupation are related to career trajectories. Careers are structural features of the labor market, and the movement of workers along career paths represent the interplay between structural and individual characteristics. In Nordic countries, individuals have higher labor market integration than elsewhere but also have more flexible and heterogeneous careers, which have become longer (Möhring, 2016). For most cohorts, careers peak in the first 5-10 years in the labor market and the progress flattens out after 30-40 years of age (Härkönen and Bihagen, 2011). Career characteristics have also changed. Van Winkle and Fasang (2017) analyzed cross-cohort variations among 14 European countries and found that the complexity of employment trajectories has increased over birth cohorts.

\section{Finnish context and societal and institutional changes}

The overall context of Finnish economic development has had a major impact on the opportunities available to different generations. The labor-force growth stopped in the early 1960s, and economic growth has since depended on increases in productivity rather than in labor inputs. By the end of the 1980s, Finland caught up with Sweden in terms of GDP per capita for the first time. In the early 1990s, the collapse of the Soviet trade, Western European recession, and problems in adjusting to the new liberal order of international capital movement led the Finnish economy into a depression. GDP fell by over $10 \%$ in three years, and unemployment rose to $18 \%$, which hit hard 
especially those entering the labor markets. The economy revived to a brisk growth rate in 19942005. The post-2008 recession has not brought about sustained increases in unemployment, but the extremely low GDP growth rate has wielded increasing pressure on the financial base of the welfare state. Key figures on historical changes are shown in figure 1.
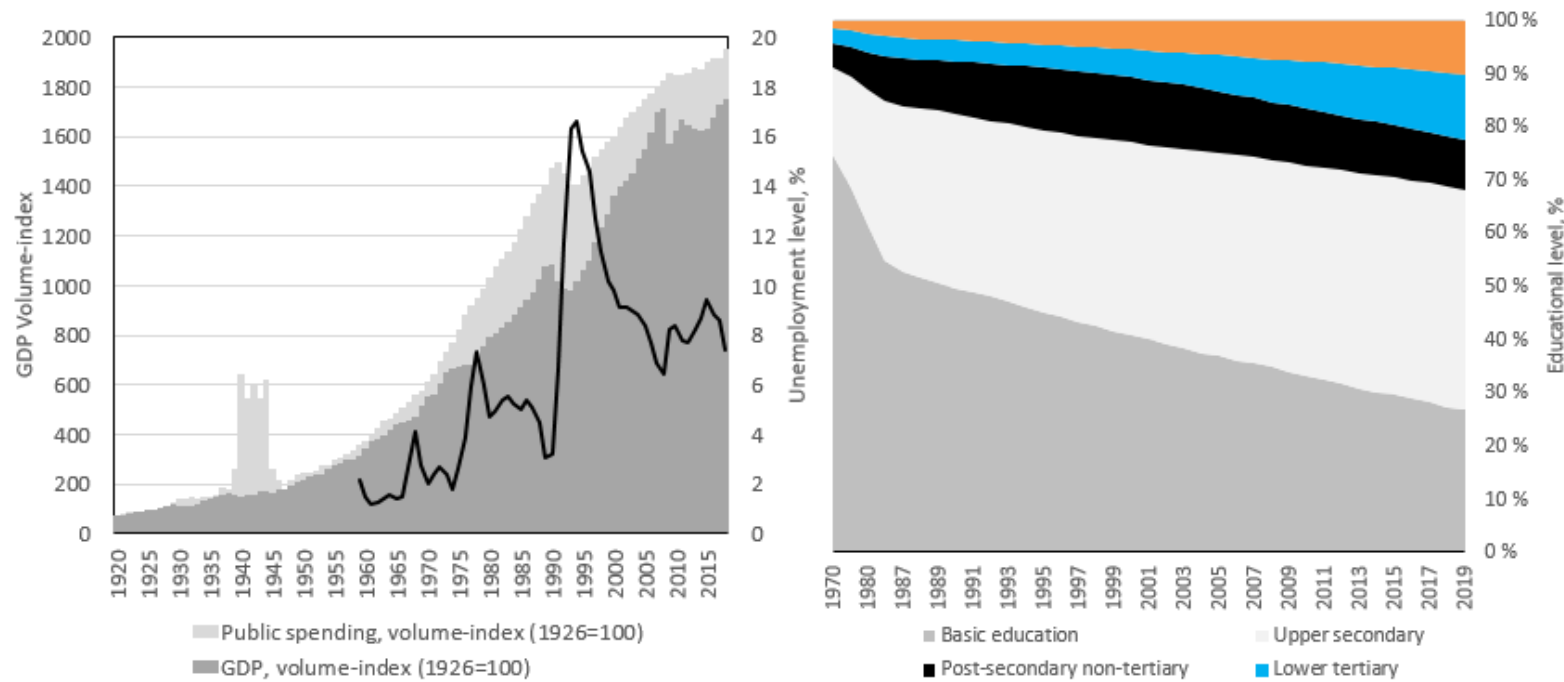

Public spending, volume-index (1926=100)

GDP, volume-index (1926=100)

- Post-secondary non-tertiary nower tertiary

-Unemployment level

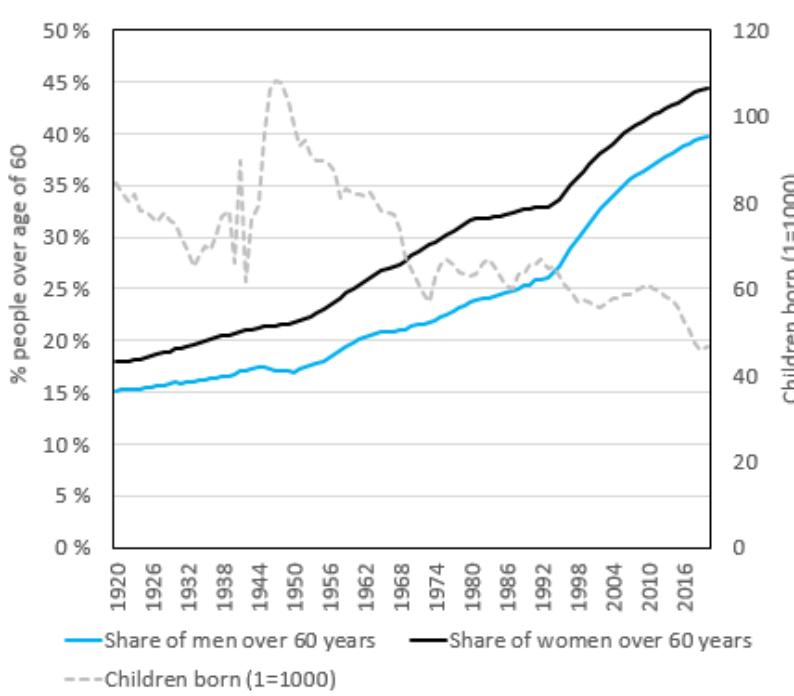

nigher tertiary

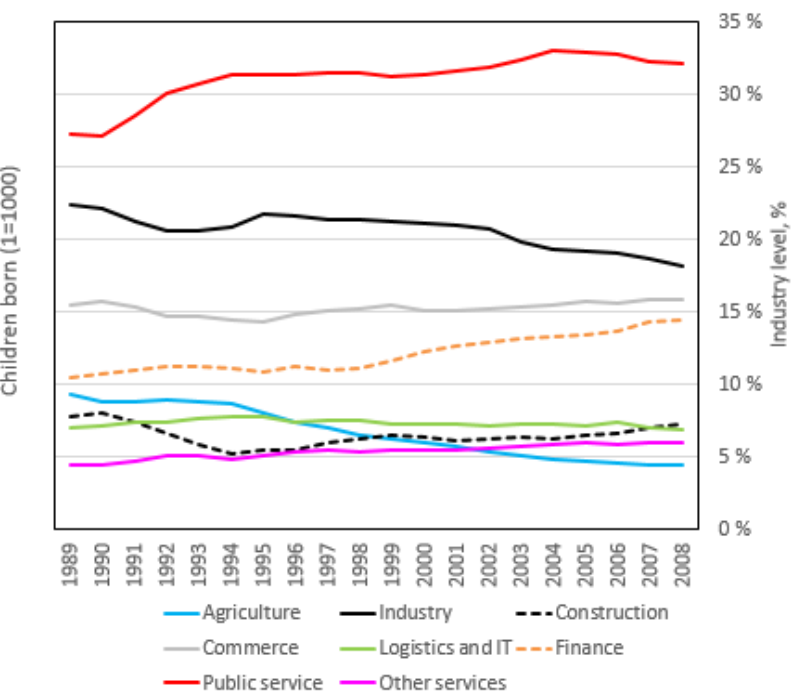

Figure 1. Key figures on GDP, public spending, unemployment level, education, employment, occupational field structure, and fertility by measurement year. 
The development of the welfare state had major implications on the Finnish class and occupational structure. The two most striking changes in Finland's class structure after WWII were the steep drop in the size of the farming population and the great expansion of the lower middle class. In the early 1950s, the number of those working in agriculture increased but thereafter fell steadily. This trend was the result of a lack of work in the agriculture sector, which incentivized people to seek employment in the cities. In the 1980s, the share of workers employed in agriculture had dropped to one-quarter of its size compared to the 1950s, while the share of those active in manufacturing and services had increased drastically. The upper and middle classes had grown since WWII, doubling in size between 1960 and 1980 (Alestalo, 2007). Today, by OECD measuring standards, approximately $80 \%$ of the population belongs to the middle class (Karonen et al., 2017).

The economic growth and expanse of the welfare state changed the economic opportunities for different generations. The cohorts born before WWII are often called the war generation (Alestalo, 2007; Antikainen and Kauppila, 2002). Their lives were shaped by the aftermath of 1918s Civil War, the World Wars, and the 1930s great depression. Educational opportunities were scant and prospects for education were minimal (Antikainen and Kauppila, 2002). The birth rate increased soon after WWII was over and created the "baby boom generation," an exceptionally large generation in Finland; however, the period of increasing birth rate was shorter than that in other European countries (Karisto, 2007). As such, Finland is the first European country to experience the demographic and labor market changes attributed to the retirement of baby boomers (Timonen and Kautto, 2014).

The cohort born in the $1960 \mathrm{~s}$ is seen as the welfare generation for having many education opportunities (Antikainen and Kauppila, 2002). Education levels increased rapidly as the reform 
of the basic education system in 1972 brought equal educational opportunities for all, irrespective of social background (see Pekkarinen et al., 2009). The birth cohorts of the 1970s were raised in a society that was socially and economically different: the economy was prosperous and spending on welfare increased rapidly in the 1980s. All this came to an end with the economic crisis in the early 1990s, with the cohorts of the 1970s entering a very different labor market than the cohorts born before them. The birth cohorts of the late 1960s and 1970s are often referred to as a precarious generation owing to their labor market experiences: they were at high risk of unemployment.

Research has identified five main points regarding the different mechanisms linked to income development. First, the empirical between-generation effects of economic shocks are found in the Finnish context among the younger generation (Riihelä, 2006), who attained a lower income level than expected according to the life-cycle hypothesis. Second, many developments have occurred in social security and non-labor earnings over the years. For example, from 1972 onward, students receive student benefits, which have greatly supported the educational expansion. Third, almost half of the Finnish population have bachelor's degrees or higher; thus, there is higher competition in the labor market, which can lead to educational inflation (Lehti and Karonen, 2019). Fourth, the occupational structure has changed from agriculture and industry to a more service-based economy. Intergenerational income mobility did not seem to increase much beyond the levels achieved among the "baby boomer" cohorts born in 1945-1950, although these older cohorts benefitted from educational expansion and a more advantageous labor market situation (Pekkala and Lucas, 2007; Pekkarinen et al., 2009; Suoniemi, 2012). Lastly, demographic change has been significant, as baby boomers had more children per family unit than cohorts from the year 1970 forward, where the average number of children almost halved.

\section{Research questions, data, and methods}




\section{Research questions}

Our first research question is on how much generational income inequality explains total income inequality during 1970-2018 for men and women in Finland. Second, we studied which structural factors contributed to generational income inequality. We observed how income trajectories over age have developed between cohorts and showed how structural factors contributed to these income trajectories. Particularly, we observed whether each successive birth cohort had a higher income, as Atkinson (2015) hypothesized. We studied five structural factors associated with generational income inequality: a) the socioeconomic and educational composition of society, b) labor market participation, c) unemployment, d) family demographic changes, and f) welfare state benefits and other non-labor income. All the analyses were computed separately for men and women, because income trajectories and the factors that may be associated with cohort income inequalities could differ according to sex.

\section{Data}

We used the register data of the Official Statistics of Finland, which provides information on the total population. Our sample from this data contained 4.4 million individuals from 1970 to 2018. Each person was followed until the end of the data period, and possible new family members were added into the panel and followed. The data were combined with information from the population register, tax register, and several other official registers (see Statistics of Finland, 2001). The data allowed us to follow the income trajectories of cohorts born 1920-1983 for four decades of the working-age population aged 20-65 years. We excluded individuals under 20 years old, because of the mandatory military- and civilian service, and people who have retired, as the issue of retirement age requires more specialized study. The data covered the years 1970 to 2018, and included information on five-year intervals from 1970 to 1985 and with annual information from 
1987 onwards. Because of data restrictions, we used quinquennial information of the data. The dataset allowed us to follow individuals' income trajectories over age and between cohorts.

\section{Dependent variable}

Our dependent variable was the individual taxable annual income, which is inflation-adjusted to 2018's monetary value and log-transformed. This variable encompassed all taxable annual (pretax) income: earned income, capital income, and a majority of social benefits. Earned income is that other than capital income. Although the data are excellent in their coverage, they exclude some non-taxable incomes, such as means-tested, last-resort social assistance benefits. We measured taxable annual income separately for men and women. For the figures, we used an inverse function for log-transformed income to report income as euros, to make the interpretation more intuitive.

\section{Independent variables}

We measured the occupational structure according to Erikson-Goldthorpe's class classification. Traditionally, Goldthorpe/Erikson/Portocarero class schemes (EGP) comprise ten categories, but we used only seven classes to harmonize with the older registers of 1970-1980: higher service (I); lower service (II); higher routine non-manual (IIIa); small proprietors and employees (IVa); selfemployed farmers (IVc); lower technicians (V); and routine non-manual workers, administration and sales and services semi-/unskilled manual workers (IIIb+VIIa+b). For those without previous information on occupations, we included an additional category.

We measured education, a continuous variable, in years. The indicator referred to the highest acquired degree and the years required to attain the education level. Finland has a compulsory education system, which puts the minimum years of education to 9 years, whereas the maximum years of education is 21 years. Unemployment was measured as the number of months at the end of the year; thus, the unemployed include those not being employed for any particular reason 
(pension, studying, home caring, etc.). The family structure was covered by a variable for the number of children. It has nine categories: no children, each children reported from 1 up to 8 children, and separate category for 9 or more.

To estimate the role of non-earnings-related income, such as income transfers, we removed workrelated income from the total income. To elaborate, we deducted wage, business, and property income from the total taxable income. The remaining income consisted of received income transfers: social security benefits, social assistance, and other current transfers received. To control for structural changes in the demographic age structure, we created an indicator separately for men and women that contained a yearly share of the population over 50 years old.

\section{Methods}

We used three-level random intercept regression models, separately for men and women, in which the observations are clustered according to cohorts and individuals, to acquire individual-, age-, and cohort-specific variances. We controlled for age in five-year interval categories for all the models, including baseline models, because birth cohorts include individuals who have different age spans. To address the question of which specific variables have contributed to generational income inequality, we used variance decomposition methods.

First, we estimated variance components in baseline models that controlled for age in five-year interval categories. Second, we decomposed variance from the baseline models adding each explanatory variable individually to the models. Finally, we estimated variance components for full models that included all the explanatory variables. We provided variance components and ICC showing how much cohort-specific differences in income before and after adjustments explain the total variance (cohort + age + individual). ICC is considered a measurement for the degree of generational income inequality. The models we estimated can be expressed as follows: 
$Y=\beta_{0}+\beta X_{c i t}+\tau_{c}+\mu_{c i}+\varepsilon_{c i t}$

$Y=\beta_{0}+\beta X_{c i t}+\beta Z_{c i t}+\tau_{c}+\mu_{c i}+\varepsilon_{c i t}$

$\mathrm{Y}$ denotes income that is the dependent variable, $\beta_{0}$ is an overall intercept, and $\beta X_{c i t}$ is the age of the individuals that is adjusted for in all the models. $Z_{c i t}$ describes the observed cohort and individual characteristics for each independent variable; residual $\tau_{c}$ reflects differences owing to unobserved cohort-level heterogeneity, which does not vary between individuals of the same cohort. $\mu_{c i}$ refers to unobserved individual-level heterogeneity, which is constant for each individual, and $\varepsilon_{c i t}$ refers to the residual variance within individuals owing to age.

The random intercept model allowed for comparing cohort- and individual-level variances with the total variance in the model: $\sigma_{\text {cohort }}^{2}+\sigma_{\text {individual }}^{2}+\sigma_{\text {age }}^{2}$. The amount of variance explained by the cohort with respect to the total variance was calculated by $\rho_{\text {cohort }}=\frac{\sigma_{\text {cohort }}^{2}}{\sigma_{\text {cohort }}^{2}+\sigma_{\text {individual }}^{2}+\sigma_{\text {age }}^{2}}$, which indicates the share of generational income inequality. $\rho_{\text {individual }}=$ $\frac{\sigma_{\text {individual }}^{2}}{\sigma_{\text {cohort }}^{2}+\sigma_{\text {individual }}^{2}+\sigma_{\text {age }}^{2}}$ measures how much invidiual variation in income explains from total variation. When $\rho_{\text {cohort }}$ and $\rho_{\text {individual }}$ are multiplied by 100 , the value can be interpreted as the degree to which cohort and individual variations explain generational income inequality as percentages of the total variation.

In the second part of the analysis, we estimated the income trajectories by age between cohorts. We added an interaction term between cohort and age. We used repeated-measures linear regression implementing the method of generalized estimation equations (GEE). The GEE method estimates population-averaged effects taking into account in within-subject correlations of repeated measurements by assuming a correlation structure between them (Twisk, 2004). The 
model corrects for this correlation, and the correlation structure is treated as a nuisance variable. We used an exchangeable correlation structure, which is the same as a random coefficient analysis. In the interaction models, we computed age and cohort variables under categorical variables, because we presented the results in easy-to-interpret graphical form.

We categorized age in five-year intervals, with the first age group being 20-24 years and the last, 56-60 years. Cohorts were categorized in ten-year interval groups for better interpretation, with the first category being 1920-1929 and the last, 1980-1983. We also measured empty models for all cohorts as a robustness check (Appendix figures A.9 and A.10). We estimated the two-way cohort $\mathrm{x}$ age interaction effects for income in eight separate regressions, where different control variables were added to the interaction model. We also observed how the different control variables changed (and thus explained) the differences in income trajectories between cohorts. The models also included the empty model (only cohort and age interaction) and the full model with all variables present. Finally, we plotted income trajectories as predicted means separately for men and women and by different cohorts. The predicted means are also displayed in the appendix tables A.3 and A.4. Further, we calculated variance components (shown in appendix tables A.5 and A.6) for each age group to show how much generational income differences explain the total income differences in different phases of the life course.

\section{Results}

\section{Generational income inequality by sex}

First, we studied how much generational income inequality explains total income inequality and what factors explain generational income inequality by calculating the ICC for cohort and individual levels. Table 1 shows the variance components and ICC for the baseline and decomposed models by sex. 
Table 1. Variance components and ICCs of baseline and decomposed models for logarithm income. Three-level random intercept models.

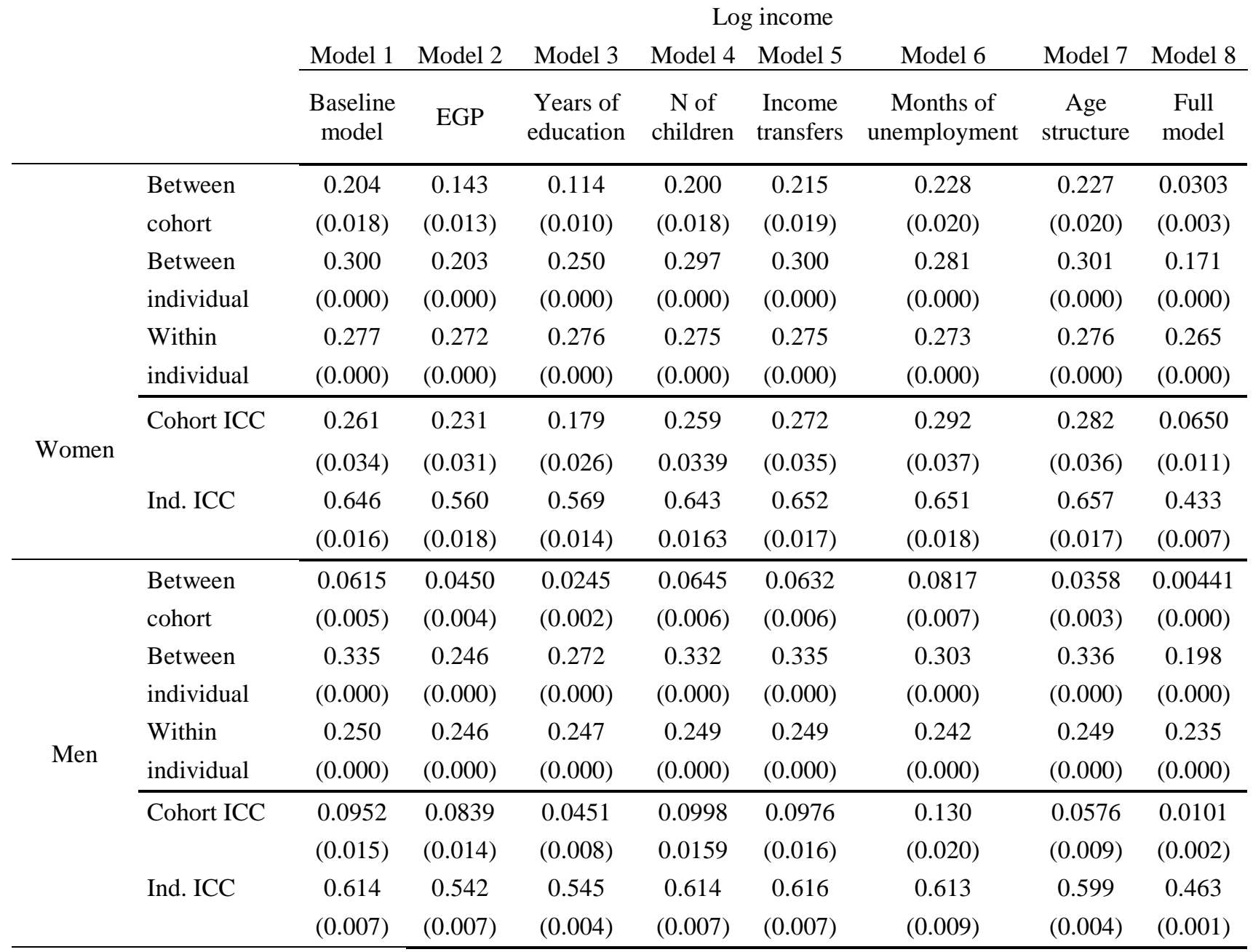

Standard errors in parentheses

Note: all estimates statistically significant, $(\mathrm{p}<0.001)$

As shown by the baseline model ICC for women, $26.1 \%$ of the income inequality is explained by cohort differences. Decomposed models 2-8, in which structural factors had been adjusted for, showed that education and number of children explained the most and least of the between-cohort income inequality, respectively. Between cohorts, variance decreased by $44 \%((0.114 / 0.204)-1))$ when education was controlled for compared with baseline model; cohort ICC changed by 8.2 percentage points $(0.261-0.179=0.082)$. Occupational class by EGP explained the substantive 
share of the between-cohort variance. The cohort variance decreased by $30 \%((0.143 / 0.204)-1))$. However, because between-individual variance also decreased about the same amount as the EGP, the cohort ICC changed only 3 percentage points from the baseline model. Unemployment increased between-cohort income variance by $12 \%$. Controlling for age structure increased between-cohort variance by $11 \%$. After controlling for the number of children and income transfers, ICC showed no practical change and cohort variance changed by less than 5\%. Thus, these two variables did not seem to influence generational income differences.

For men, the baseline ICC showed that cohort differences in income explained $9.5 \%$ of the total income differences on average (Table 1). For women, the corresponding value is approximately one-third. Thus, compared with women, men's income inequalities were much less explained by their cohort. For women, decomposed models $2-8$ showed that education explained most of the between-cohort income inequality compared with other factors. When education was controlled for, cohort income variance decreased by $60 \%$ and ICC decreased by 5 percentage points. For both women and men, EGP decreased between-cohort variance by $27 \%$. However, as betweenindividual variance changed by the same amount, ICC changed by only 1 percentage point. Age structure decreased cohort variance by $42 \%$ and ICC by 4 percentage points. Thus, if given a constant age structure is held constant income differences would decrease. Different birth cohorts encounter different labor market situations, which are linked to age structure in the labor markets. For example, individuals in younger birth cohorts have more difficulty attaching to labor markets and adhering to a decent income trajectory if they have to compete for jobs with not only individuals in the same birth cohort but also individuals from previous birth cohorts.

Unemployment increased cohort differences for men. Between-cohort variance increased by about $33 \%$ and ICC, 3 percentage points. Thus, unemployment benefits (returns to unemployment) had 
not been the same for all birth cohorts. Holding unemployment constant over the birth cohorts, the income differences increased compared with the baseline model. After controlling for the number of children and income transfers, ICC showed no change and cohort variance changed by less than $5 \%$. Thus, these two variables did not seem to influence generational income differences.

Given that variance components or cohort ICCs did not show how the mean income trajectories of the birth cohorts differed over the life course, we analyzed the next mean income trajectory differences between cohorts by age group and showed how income trajectories changed when certain variables were taken into account in the models.

\section{Generational income trajectories}

We observed how income trajectories over age developed between cohorts and showed how structural factors contributed to these income trajectories. Particularly, we intended to determine whether each successive birth cohort had a higher income or whether some younger cohorts were getting left behind. Figures 2 and 3 describe the income trajectories by age and cohort groups for the average income for both men and women for the period 1970-2018. Each panel represents a model for a controlled for variable. The first panel is the empty model that does not include any controls to model.

In Figure 2, the empty model for men shows that each successive cohort had a higher average income trajectory: the oldest cohort born in the 1920s had the lowest average income level and the youngest cohorts had the highest. On average, the increase in income was $13 \%$ between 10-year cohorts (see percent numbers in Appendix table A.5). However, the average income of the 1980s cohort did not increase from that of the 1970s cohort at the ages 30-34 and 35-39 years. In these age groups, income was 1-2\% lower for the 1980s birth cohort compared with the 1970s cohort. 
Appendix table A.7 shows cohort variances calculated over individual birth cohorts according to the age groups ${ }^{1}$. The empty model showed that cohort differences in income were the highest for the youngest and oldest age groups. However, for men, cohort variances in every age group were small compared with individual variances. Education explained most of the cohort variance for individuals aged over 25 years, which is the average age when the highest education level is attained. Unemployment increased cohort variance among all the age groups. However, this mostly applies to the 35-59 years old age groups. Controlling for the age structure explained practically all of the cohort variance from the age 25 to 64 years.

\footnotetext{
${ }^{1}$ Cohort variances are calculated over single individual birth cohorts. Figures in the results section contain the mean of the 10-year cohort to make results easier to read.
} 

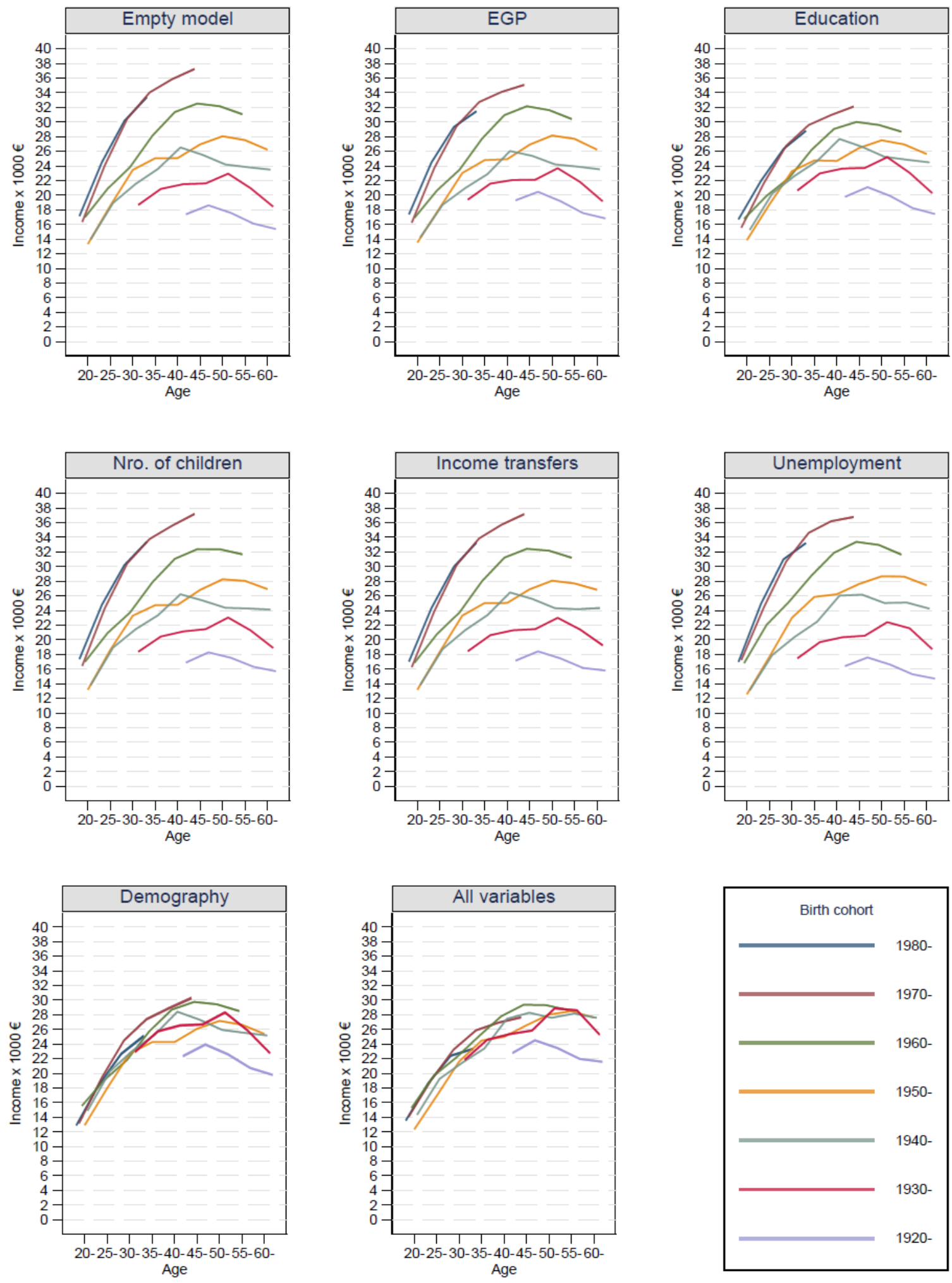

Figure 2. Average absolute income trajectories of birth cohorts (1920s-1980s) in euros for 1970-2018, men. 
Among women, the empty model showed an increasing trend from the oldest to the youngest cohort in average income trajectories (Fig. 3). However, compared with men, differences in income trajectories between cohorts were much larger. On average, the increase in income between the cohorts' groups is $25 \%$ (see percent numbers in Appendix table A.6). Similar to the men's results, average income trajectories for the 1980s cohort showed near stagnation compared with the 1970s cohort; for the 35-39 years age group, income decreased compared with the 1970s birth cohort. In this age group, income was $2 \%$ lower for the 1980s birth cohort compared with the 1970s cohort.

Appendix table A. 8 shows the cohort variances for women calculated over individual birth cohorts according to the age groups. As shown in the empty model, cohort differences in income were the highest in the oldest age groups (45-64 years). For women, cohort variances in every age group were smaller compared with individual variances. Particularly in the older age groups, between cohort differences were much larger than that for men. For women, EGP, education, unemployment, and age structure partly explained the cohort variation in different age groups. EGP explained a larger portion from the 40-44 years to the 60-64 age group, the age where individuals reach their highest occupational status (Härkönen and Bihagen, 2011). Thus, the returns of the social class among women decreased between cohorts from age 40 to 64 years. As with the case for men, education explained most of the cohort variance over the life course in individuals aged over 25 years. Unemployment increased cohort variance among all the age groups; however, this mostly applied to the 35-59 age groups. Controlling for the age structure explained practically all of the cohort variance from the age 25 to 64 years. 

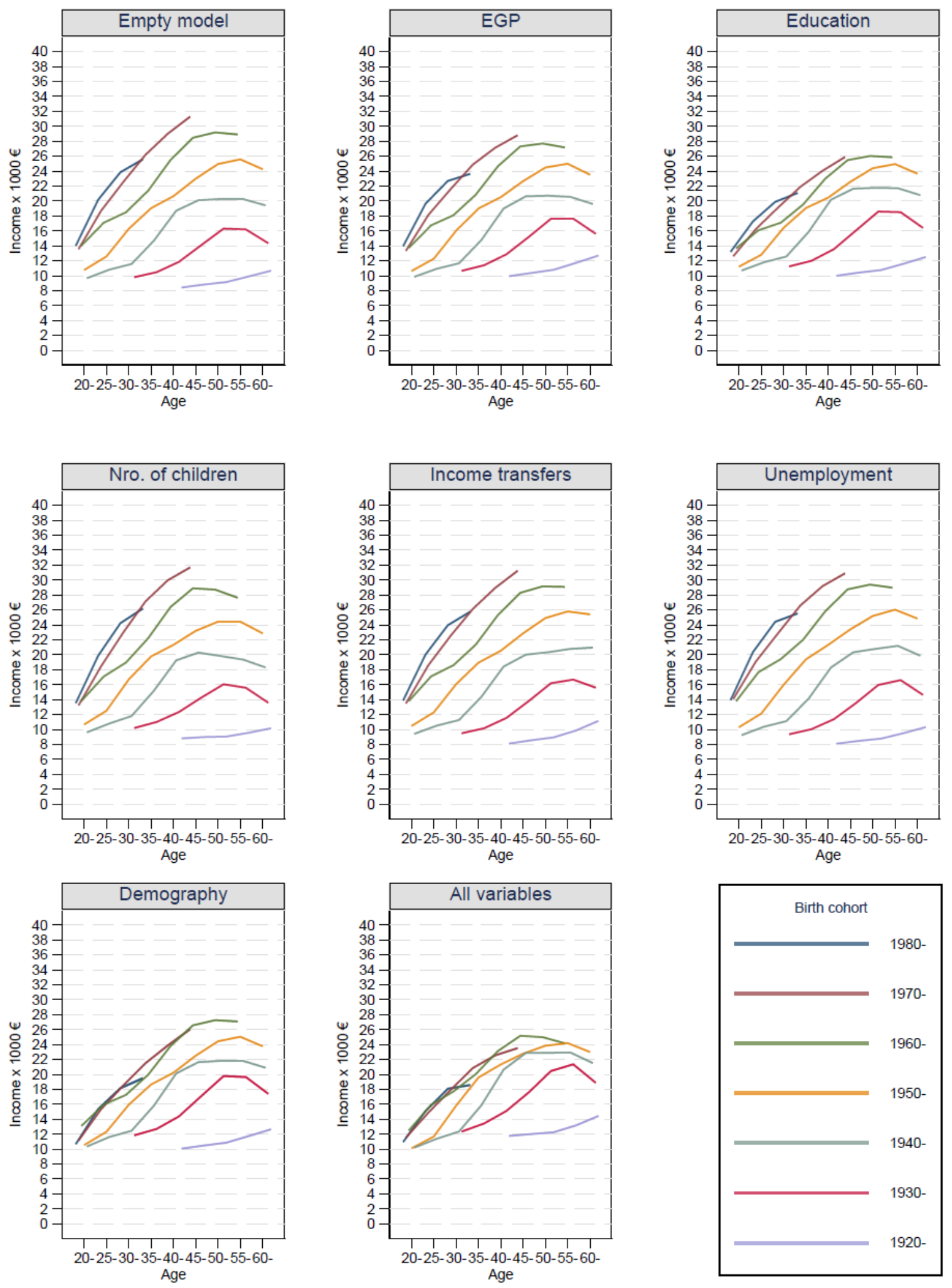

Figure 3. Average absolute income trajectories of birth cohorts (1920s-1980s) in euros in the period 1970-2018, women. 


\section{Conclusion}

We examined how much generational income inequality explained total income inequality, and what factors contributed to possible cohort income differences. We also observed how income trajectories between cohorts developed over age and whether younger cohorts may be getting left behind. Our results showed that in the period of 1970-2018, cohort differences explained $26 \%$ and $6 \%$ of the total income inequality in women and men, respectively. Overall, for men and women, each successive cohort until 1980s had a higher average income trajectory. However, for women, differences in income trajectories between cohorts were much larger compared with men.

Our results support previous findings that the younger generation is being left behind. By the 1980s, cohort average income had not increased from the 1970s income for both men and women. This could be attributed to economic downturn, as the 1980s cohort did face a financial and euro crisis and unemployment at the beginning of their working life. However, unemployment alone could not explain the stagnated trajectory of the cohort born in the 1980s because our results showed almost the same trajectory even after controlling for unemployment. One explanation is that the cohort delayed their labor market entry and, thus, their income trajectories did not develop as expected. Moreover, stagnated earnings development in Europe in this period can be one part of the explanation. In liberal welfare states and most social democratic ones, a cohort's lifetime incomes have been shown to be unaffected by the specific economic situation upon entry to the labor market (Chauvel and Schroder, 2014; Tepe and Vanhuysse, 2009). However, our analyses for the 1980s cohort did not support this idea.

For both men and women, age structure and education were the most important factors that explained different generational income trajectories. These two factors are linked. First, the age structure defines the ratio of old and young people, which is important as those cohorts who 
benefitted from the educational expansion and lower labor market competition, combined with high employment rate, had the opportunity to secure labor market positions. Thus, even if younger cohorts are increasingly educated, opportunities to enter the job market may not exist similarly, as previous cohorts could already hold the profitable positions. Thus, when the labor market has already extensive amount of those holding careers, then high positions may no longer be broadly available; thus, returns to education decrease. Particularly this applies in the period of economic downturn, such as euro crisis (2008-2009 and 2012-2015), which weakens labor market attachment and employment opportunities. Overall, our findings support the previous results that credential inflation contributes to income inequalities between cohorts (Bol, 2015; Van de Werfhorst and Andersen, 2005), as we observed lowered income trajectories among younger cohorts compared to older ones when education is adjusted for. As educational expansion has focused mostly on higher education levels, then it is reasonable to assume that returns of higher degrees have diminished for younger generations.

For women, we found that EGP explain the larger portion of the cohort difference when they reach the 40-64 years age groups, which coincide with individuals reaching their highest occupational status (Härkönen and Bihagen, 2011). Thus, the returns of the occupational class among women decreased among the cohorts aged 40-64 years. These age groups experienced the periods before and during major changes in occupational structures that occurred in the 1970s and 1980s (Breen et al., 2009, 2010), which changed women's participation in the labor market. Increased labor market participation increased the competition among women, which could have decreased returns to occupation. In addition to stability of career among women in Nordic countries, career paths are typically flexible and heterogeneous to accommodate childrearing. For men, we did not observe such association with EGP and income. 
The number of children was relevant for women, whose income stagnated between the ages of 20 and 35 years depending on cohort. Previous study in Finland has shown that income levels recovered after 5 to 10 years, depending on the number of children (Sieppi and Pehkonen, 2019). However, the number of children did not contribute to the overall income inequality among women, as the average number of children remained the same during analyzed period.

Our study showed that the assumption that the future generation will always have better living standards is only partly supported. The youngest generation born in the 1980s has been falling behind on average income development. We also confirmed that in the Nordic welfare society context, cohort incomes continue to be affected by economic shocks at sensitive times of the life course. The lower income trajectory of the "less lucky generation" born in the 1980s is a worrisome development as welfare societies need continuity with regard to the funding of public spending. Future research should elaborate on this point in a more detailed manner.

The limitations of our research are connected to the nature of cohort research: we could not collect all the information on the subjects' life course. Cohort studies tend to lack observations for both extremes of the age distribution, as some of the cohorts are too young or old relative to the measurement period. For further research on between-cohort income distribution, a fruitful path would be the consideration of how the aging of the population impacts analyses, as it plays a major role in income inequality. Further, the decomposed results could not show causal effects. Our models could not account for unobserved factors that correlate with the explanatory variables used in the study. 


\section{APPENDIX}

Table A.1. Three-level random intercept models: variance components and ICCs of baseline and decomposed models for absolute income. Models for men.

\begin{tabular}{|c|c|c|c|c|c|c|c|c|}
\hline & $\begin{array}{c}(1) \\
\text { Baseline } \\
\text { model }\end{array}$ & $\begin{array}{c}(2) \\
\text { EGP }\end{array}$ & $\begin{array}{c}\text { (3) } \\
\text { Years of } \\
\text { education }\end{array}$ & $\begin{array}{c}(4) \\
\mathrm{N} \text { of } \\
\text { children }\end{array}$ & $\begin{array}{c}(5) \\
\text { Income } \\
\text { transfers }\end{array}$ & $\begin{array}{l}\text { (6) } \\
\text { Months } \\
\text { of } \\
\text { unemp. }\end{array}$ & $\begin{array}{c}(7) \\
\text { Age } \\
\text { structure }\end{array}$ & $\begin{array}{c}(8) \\
\text { Full } \\
\text { model }\end{array}$ \\
\hline \multicolumn{9}{|l|}{$\begin{array}{l}\text { 20-24 years } \\
\text { (Ref.) }\end{array}$} \\
\hline $25-29$ years & $\begin{array}{c}0.312 \\
(0.001)\end{array}$ & $\begin{array}{c}0.296 \\
(0.001)\end{array}$ & $\begin{array}{c}0.273 \\
(0.001)\end{array}$ & $\begin{array}{c}0.319 \\
(0.001)\end{array}$ & $\begin{array}{c}0.313 \\
(0.001)\end{array}$ & $\begin{array}{c}0.327 \\
(0.001)\end{array}$ & $\begin{array}{c}0.297 \\
(0.001)\end{array}$ & $\begin{array}{c}0.299 \\
(0.001)\end{array}$ \\
\hline $30-34$ years & $\begin{array}{c}0.499 \\
(0.001)\end{array}$ & $\begin{array}{c}0.474 \\
(0.001)\end{array}$ & $\begin{array}{c}0.442 \\
(0.001)\end{array}$ & $\begin{array}{c}0.498 \\
(0.001)\end{array}$ & $\begin{array}{c}0.501 \\
(0.001)\end{array}$ & $\begin{array}{c}0.521 \\
(0.001)\end{array}$ & $\begin{array}{c}0.467 \\
(0.001)\end{array}$ & $\begin{array}{c}0.470 \\
(0.001)\end{array}$ \\
\hline $35-39$ years & $\begin{array}{c}0.609 \\
(0.001)\end{array}$ & $\begin{array}{c}0.583 \\
(0.001)\end{array}$ & $\begin{array}{c}0.545 \\
(0.001)\end{array}$ & $\begin{array}{c}0.602 \\
(0.001)\end{array}$ & $\begin{array}{c}0.613 \\
(0.001)\end{array}$ & $\begin{array}{c}0.636 \\
(0.001)\end{array}$ & $\begin{array}{c}0.563 \\
(0.001)\end{array}$ & $\begin{array}{c}0.579 \\
(0.001)\end{array}$ \\
\hline $40-44$ years & $\begin{array}{c}0.672 \\
(0.001)\end{array}$ & $\begin{array}{c}0.650 \\
(0.001)\end{array}$ & $\begin{array}{c}0.605 \\
(0.001)\end{array}$ & $\begin{array}{c}0.665 \\
(0.001)\end{array}$ & $\begin{array}{c}0.677 \\
(0.001)\end{array}$ & $\begin{array}{c}0.709 \\
(0.001)\end{array}$ & $\begin{array}{c}0.607 \\
(0.001)\end{array}$ & $\begin{array}{c}0.658 \\
(0.001)\end{array}$ \\
\hline $45-49$ years & $\begin{array}{c}0.700 \\
(0.001)\end{array}$ & $\begin{array}{c}0.683 \\
(0.001)\end{array}$ & $\begin{array}{c}0.632 \\
(0.001)\end{array}$ & $\begin{array}{c}0.701 \\
(0.001)\end{array}$ & $\begin{array}{c}0.708 \\
(0.001)\end{array}$ & $\begin{array}{c}0.747 \\
(0.001)\end{array}$ & $\begin{array}{c}0.618 \\
(0.001)\end{array}$ & $\begin{array}{c}0.709 \\
(0.001)\end{array}$ \\
\hline $50-54$ years & $\begin{array}{c}0.696 \\
(0.001)\end{array}$ & $\begin{array}{c}0.682 \\
(0.001)\end{array}$ & $\begin{array}{c}0.627 \\
(0.001)\end{array}$ & $\begin{array}{c}0.709 \\
(0.001)\end{array}$ & $\begin{array}{c}0.708 \\
(0.001)\end{array}$ & $\begin{array}{c}0.752 \\
(0.001)\end{array}$ & $\begin{array}{c}0.597 \\
(0.001)\end{array}$ & $\begin{array}{c}0.731 \\
(0.001)\end{array}$ \\
\hline $55-59$ years & $\begin{array}{c}0.649 \\
(0.001)\end{array}$ & $\begin{array}{c}0.638 \\
(0.001)\end{array}$ & $\begin{array}{c}0.580 \\
(0.001)\end{array}$ & $\begin{array}{c}0.674 \\
(0.001)\end{array}$ & $\begin{array}{c}0.672 \\
(0.001)\end{array}$ & $\begin{array}{c}0.727 \\
(0.001)\end{array}$ & $\begin{array}{c}0.533 \\
(0.001)\end{array}$ & $\begin{array}{c}0.726 \\
(0.001)\end{array}$ \\
\hline $60-64$ years & $\begin{array}{c}0.588 \\
(0.001)\end{array}$ & $\begin{array}{c}0.577 \\
(0.001)\end{array}$ & $\begin{array}{c}0.519 \\
(0.001)\end{array}$ & $\begin{array}{c}0.621 \\
(0.001)\end{array}$ & $\begin{array}{c}0.635 \\
(0.001)\end{array}$ & $\begin{array}{c}0.667 \\
(0.001)\end{array}$ & $\begin{array}{c}0.456 \\
(0.001)\end{array}$ & $\begin{array}{c}0.684 \\
(0.001)\end{array}$ \\
\hline $\begin{array}{l}\text { Higher service } \\
\text { (I) (Ref.) }\end{array}$ & & & & & & & & \\
\hline $\begin{array}{l}\text { Lower service } \\
\text { (II) }\end{array}$ & & $\begin{array}{l}-0.140 \\
(0.001)\end{array}$ & & & & & & $\begin{array}{l}-0.0927 \\
(0.001)\end{array}$ \\
\hline $\begin{array}{l}\text { Higher routine } \\
\text { non-manual } \\
\text { (IIIa) }\end{array}$ & & $\begin{array}{l}-0.310 \\
(0.002)\end{array}$ & & & & & & $\begin{array}{l}-0.228 \\
(0.001)\end{array}$ \\
\hline $\begin{array}{l}\text { Small } \\
\text { proprietors + } \\
\text { employees } \\
\text { (IVa) }\end{array}$ & & $\begin{array}{c}-0.581 \\
(0.001)\end{array}$ & & & & & & $\begin{array}{l}-0.497 \\
(0.001)\end{array}$ \\
\hline $\begin{array}{l}\text { Self-employed } \\
\text { farmers (IVc) }\end{array}$ & & $\begin{array}{l}-0.927 \\
(0.001)\end{array}$ & & & & & & $\begin{array}{l}-0.813 \\
(0.001)\end{array}$ \\
\hline $\begin{array}{l}\text { Lower } \\
\text { technicians } \\
\text { (V) }\end{array}$ & & $\begin{array}{l}-0.375 \\
(0.001)\end{array}$ & & & & & & $\begin{array}{l}-0.201 \\
(0.001)\end{array}$ \\
\hline $\begin{array}{l}\text { Semi- } \\
\text { /unskilled } \\
\text { manual (IIIb + } \\
\text { VIIa+ b) }\end{array}$ & & $\begin{array}{c}-0.443 \\
(0.001)\end{array}$ & & & & & & $\begin{array}{l}-0.282 \\
(0.001)\end{array}$ \\
\hline $\begin{array}{l}\text { Years of } \\
\text { education }\end{array}$ & & & $\begin{array}{l}0.0945 \\
(0.000)\end{array}$ & & & & & $\begin{array}{l}0.0653 \\
(0.000)\end{array}$ \\
\hline
\end{tabular}




\begin{tabular}{|c|c|c|c|c|c|c|c|c|}
\hline $\mathrm{N}$ of children & & & & $\begin{array}{l}0.0272 \\
(0.000)\end{array}$ & & & & $\begin{array}{l}0.0278 \\
(0.000)\end{array}$ \\
\hline Income & & & & & $-0.378 e-5$ & & & -0.0380 \\
\hline transfers & & & & & $(0.000)$ & & & $(0.000)$ \\
\hline Months of & & & & & & -0.0370 & & $-0.136 e-5$ \\
\hline unemployment & & & & & & $(0.000)$ & & $(0.000)$ \\
\hline Demography & & & & & & & 1.148 & 5.425 \\
\hline & & & & & & & $(0.007)$ & $(0.242)$ \\
\hline Constant & 9.491 & 9.888 & 8.509 & 9.452 & 9.492 & 9.500 & 9.233 & 7.484 \\
\hline & $(0.031)$ & $(0.027)$ & $(0.020)$ & $(0.032)$ & $(0.031)$ & $(0.036)$ & $(0.024)$ & $(0.070)$ \\
\hline Between & 0.0615 & 0.0450 & 0.0245 & 0.0645 & 0.0632 & 0.0817 & 0.0358 & 0.00441 \\
\hline cohort & $(0.005)$ & $(0.004)$ & $(0.002)$ & $(0.006)$ & $(0.006)$ & $(0.007)$ & $(0.003)$ & $(0.000)$ \\
\hline Between & 0.335 & 0.246 & 0.272 & 0.332 & 0.335 & 0.303 & 0.336 & 0.198 \\
\hline individual & $(0.000)$ & $(0.000)$ & $(0.000)$ & $(0.000)$ & $(0.000)$ & $(0.000)$ & $(0.000)$ & $(0.000)$ \\
\hline Within & 0.250 & 0.246 & 0.247 & 0.249 & 0.249 & 0.242 & 0.249 & 0.235 \\
\hline individual & $(0.000)$ & $(0.000)$ & $(0.000)$ & $(0.000)$ & $(0.000)$ & $(0.000)$ & $(0.000)$ & $(0.000)$ \\
\hline Cohort ICC & 0.0952 & 0.0839 & 0.0451 & 0.0998 & 0.0976 & 0.130 & 0.0576 & 0.0101 \\
\hline & $(0.015)$ & $(0.014)$ & (0.008) & 0.0159 & $(0.016)$ & $(0.020)$ & $(0.009)$ & 0.00177 \\
\hline Ind. ICC & 0.614 & 0.542 & 0.545 & 0.614 & 0.616 & 0.613 & 0.599 & 0.463 \\
\hline & $(0.007)$ & $(0.007)$ & $(0.004)$ & 0.00682 & $(0.007)$ & $(0.009)$ & $(0.004)$ & 0.00101 \\
\hline Cohort N & 64 & 64 & 64 & 64 & 64 & 64 & 64 & 64 \\
\hline Individual N & 2233183 & 2233183 & 2233183 & 2233183 & 2233183 & 2233183 & 2233183 & 2233183 \\
\hline $\mathrm{N}$ & 13384065 & 13384065 & 13384065 & 13384065 & 13384065 & 13384065 & 13384065 & 13384065 \\
\hline
\end{tabular}

Standard errors in parentheses

Note: all estimates statistically significant, $(\mathrm{p}<0.001)$ 
Table A.2. Three-level random intercept models: variance components and ICCs of baseline and decomposed models for absolute income. Models for women.

\begin{tabular}{|c|c|c|c|c|c|c|c|c|}
\hline & $\begin{array}{c}(1) \\
\text { Baseline } \\
\text { model }\end{array}$ & $\begin{array}{c}(2) \\
\text { EGP }\end{array}$ & $\begin{array}{c}\text { (3) } \\
\text { Years of } \\
\text { education }\end{array}$ & $\begin{array}{c}(4) \\
\mathrm{N} \text { of } \\
\text { children }\end{array}$ & $\begin{array}{c}(5) \\
\text { Income } \\
\text { transfers }\end{array}$ & $\begin{array}{c}\text { (6) } \\
\text { Months of } \\
\text { unemp. }\end{array}$ & $\begin{array}{c}(7) \\
\text { Age } \\
\text { structure }\end{array}$ & $\begin{array}{c}(8) \\
\text { Full } \\
\text { model }\end{array}$ \\
\hline $\begin{array}{l}\text { 20-24 years } \\
\text { (Ref.) }\end{array}$ & & & & & & & & \\
\hline $25-29$ years & $\begin{array}{c}0.215 \\
(0.001)\end{array}$ & $\begin{array}{c}0.209 \\
(0.001)\end{array}$ & $\begin{array}{c}0.176 \\
(0.001)\end{array}$ & $\begin{array}{c}0.225 \\
(0.001)\end{array}$ & $\begin{array}{c}0.221 \\
(0.001)\end{array}$ & $\begin{array}{c}0.228 \\
(0.001)\end{array}$ & $\begin{array}{c}0.220 \\
(0.001)\end{array}$ & $\begin{array}{c}0.207 \\
(0.001)\end{array}$ \\
\hline 30-34 years & $\begin{array}{c}0.368 \\
(0.001)\end{array}$ & $\begin{array}{c}0.359 \\
(0.001)\end{array}$ & $\begin{array}{c}0.314 \\
(0.001)\end{array}$ & $\begin{array}{c}0.405 \\
(0.001)\end{array}$ & $\begin{array}{c}0.378 \\
(0.001)\end{array}$ & $\begin{array}{c}0.387 \\
(0.001)\end{array}$ & $\begin{array}{c}0.381 \\
(0.001)\end{array}$ & $\begin{array}{c}0.379 \\
(0.001)\end{array}$ \\
\hline $35-39$ years & $\begin{array}{c}0.524 \\
(0.001)\end{array}$ & $\begin{array}{c}0.513 \\
(0.001)\end{array}$ & $\begin{array}{c}0.459 \\
(0.001)\end{array}$ & $\begin{array}{c}0.574 \\
(0.001)\end{array}$ & $\begin{array}{c}0.534 \\
(0.001)\end{array}$ & $\begin{array}{c}0.544 \\
(0.001)\end{array}$ & $\begin{array}{c}0.542 \\
(0.001)\end{array}$ & $\begin{array}{c}0.541 \\
(0.001)\end{array}$ \\
\hline 40-44 years & $\begin{array}{c}0.671 \\
(0.001)\end{array}$ & $\begin{array}{c}0.659 \\
(0.001)\end{array}$ & $\begin{array}{c}0.601 \\
(0.001)\end{array}$ & $\begin{array}{c}0.716 \\
(0.001)\end{array}$ & $\begin{array}{c}0.681 \\
(0.001)\end{array}$ & $\begin{array}{c}0.695 \\
(0.001)\end{array}$ & $\begin{array}{c}0.697 \\
(0.001)\end{array}$ & $\begin{array}{c}0.684 \\
(0.001)\end{array}$ \\
\hline $45-49$ years & $\begin{array}{c}0.777 \\
(0.001)\end{array}$ & $\begin{array}{c}0.763 \\
(0.001)\end{array}$ & $\begin{array}{c}0.702 \\
(0.001)\end{array}$ & $\begin{array}{c}0.800 \\
(0.001)\end{array}$ & $\begin{array}{c}0.791 \\
(0.001)\end{array}$ & $\begin{array}{c}0.805 \\
(0.001)\end{array}$ & $\begin{array}{c}0.811 \\
(0.001)\end{array}$ & $\begin{array}{c}0.775 \\
(0.001)\end{array}$ \\
\hline 50-54 years & $\begin{array}{c}0.836 \\
(0.001)\end{array}$ & $\begin{array}{c}0.820 \\
(0.001)\end{array}$ & $\begin{array}{c}0.760 \\
(0.001)\end{array}$ & $\begin{array}{c}0.831 \\
(0.001)\end{array}$ & $\begin{array}{c}0.858 \\
(0.001)\end{array}$ & $\begin{array}{c}0.871 \\
(0.001)\end{array}$ & $\begin{array}{c}0.877 \\
(0.001)\end{array}$ & $\begin{array}{c}0.819 \\
(0.001)\end{array}$ \\
\hline $55-59$ years & $\begin{array}{c}0.859 \\
(0.001)\end{array}$ & $\begin{array}{c}0.842 \\
(0.001)\end{array}$ & $\begin{array}{c}0.783 \\
(0.001)\end{array}$ & $\begin{array}{c}0.830 \\
(0.001)\end{array}$ & $\begin{array}{c}0.900 \\
(0.001)\end{array}$ & $\begin{array}{c}0.911 \\
(0.001)\end{array}$ & $\begin{array}{c}0.907 \\
(0.001)\end{array}$ & $\begin{array}{c}0.847 \\
(0.001)\end{array}$ \\
\hline 60-64 years & $\begin{array}{c}0.827 \\
(0.001)\end{array}$ & $\begin{array}{c}0.810 \\
(0.001)\end{array}$ & $\begin{array}{c}0.752 \\
(0.001)\end{array}$ & $\begin{array}{c}0.785 \\
(0.001)\end{array}$ & $\begin{array}{c}0.916 \\
(0.001)\end{array}$ & $\begin{array}{c}0.881 \\
(0.001)\end{array}$ & $\begin{array}{c}0.881 \\
(0.001)\end{array}$ & $\begin{array}{c}0.820 \\
(0.001)\end{array}$ \\
\hline $\begin{array}{l}\text { Higher service } \\
\text { (I) (Ref.) }\end{array}$ & & & & & & & & \\
\hline $\begin{array}{l}\text { Lower service } \\
\text { (II) }\end{array}$ & & $\begin{array}{l}-0.169 \\
(0.001)\end{array}$ & & & & & & $\begin{array}{l}-0.111 \\
(0.001)\end{array}$ \\
\hline $\begin{array}{l}\text { Higher routine } \\
\text { non-manual } \\
\text { (IIIa) }\end{array}$ & & $\begin{array}{l}-0.238 \\
(0.001)\end{array}$ & & & & & & $\begin{array}{l}-0.156 \\
(0.001)\end{array}$ \\
\hline $\begin{array}{l}\text { Small } \\
\text { proprietors + } \\
\text { employees } \\
\text { (IVa) }\end{array}$ & & $\begin{array}{l}-0.744 \\
(0.001)\end{array}$ & & & & & & $\begin{array}{l}-0.628 \\
(0.001)\end{array}$ \\
\hline $\begin{array}{l}\text { Self-employed } \\
\text { farmers (IVc) }\end{array}$ & & $\begin{array}{l}-1.205 \\
(0.001)\end{array}$ & & & & & & $\begin{array}{l}-1.044 \\
(0.001)\end{array}$ \\
\hline $\begin{array}{l}\text { Lower } \\
\text { technicians } \\
\text { (V) }\end{array}$ & & $\begin{array}{c}-0.383 \\
(0.001)\end{array}$ & & & & & & $\begin{array}{l}-0.216 \\
(0.001)\end{array}$ \\
\hline $\begin{array}{l}\text { Semi- } \\
\text { /unskilled } \\
\text { manual (IIIb + } \\
\text { VIIa+ b) }\end{array}$ & & $\begin{array}{l}-0.400 \\
(0.001)\end{array}$ & & & & & & $\begin{array}{l}-0.236 \\
(0.001)\end{array}$ \\
\hline $\begin{array}{l}\text { Years of } \\
\text { education }\end{array}$ & & & $\begin{array}{l}0.0803 \\
(0.000)\end{array}$ & & & & & $\begin{array}{l}0.0596 \\
(0.000)\end{array}$ \\
\hline $\mathrm{N}$ of children & & & & $\begin{array}{c}- \\
0.0563 \\
(0.000)\end{array}$ & & & & $\begin{array}{c}-0.232 \mathrm{e}-5 \\
(0.000)\end{array}$ \\
\hline
\end{tabular}




\begin{tabular}{|c|c|c|c|c|c|c|c|c|}
\hline $\begin{array}{l}\text { Income } \\
\text { transfers }\end{array}$ & & & & & $\begin{array}{c}-0.854 \mathrm{e}-5 \\
(0.000)\end{array}$ & & & $\begin{array}{c}-0.0285 \\
(0.000)\end{array}$ \\
\hline Months of & & & & & & -0.0 & & 10.51 \\
\hline unemployment & & & & & & $(0.000)$ & & $(0.816)$ \\
\hline Demography & & & & & & & -0.640 & 0.0596 \\
\hline & & & & & & & $(0.007)$ & $(0.000)$ \\
\hline \multirow[t]{2}{*}{ Constant } & 9.126 & 9.536 & 8.284 & 9.180 & 9.130 & 9.134 & 9.295 & 5.565 \\
\hline & $(0.056)$ & $(0.047)$ & $(0.042)$ & $(0.056)$ & $(0.058)$ & $(0.060)$ & $(0.060)$ & $(0.254)$ \\
\hline \multirow{2}{*}{$\begin{array}{l}\text { Between } \\
\text { cohort }\end{array}$} & 0.204 & 0.143 & 0.114 & 0.200 & 0.215 & 0.228 & 0.227 & 0.0303 \\
\hline & $(0.018)$ & $(0.013)$ & $(0.010)$ & $(0.018)$ & $(0.019)$ & $(0.020)$ & $(0.020)$ & $(0.003)$ \\
\hline Between & 0.300 & 0.203 & 0.250 & 0.297 & 0.300 & 0.281 & 0.301 & 0.171 \\
\hline individual & $(0.000)$ & $(0.000)$ & $(0.000)$ & $(0.000)$ & $(0.000)$ & $(0.000)$ & $(0.000)$ & $(0.000)$ \\
\hline \multirow{2}{*}{$\begin{array}{l}\text { Within } \\
\text { individual }\end{array}$} & 0.277 & 0.272 & 0.276 & 0.275 & 0.275 & 0.273 & 0.276 & 0.265 \\
\hline & $(0.000)$ & $(0.000)$ & $(0.000)$ & $(0.000)$ & $(0.000)$ & $(0.000)$ & $(0.000)$ & $(0.000)$ \\
\hline \multirow[t]{2}{*}{ Cohort ICC } & 0.261 & 0.231 & 0.179 & 0.259 & 0.272 & 0.292 & 0.282 & 0.0650 \\
\hline & $(0.034)$ & $(0.031)$ & $(0.026)$ & 0.0339 & $(0.035)$ & $(0.037)$ & $(0.036)$ & 0.0107 \\
\hline \multirow[t]{2}{*}{ Ind. ICC } & 0.646 & 0.560 & 0.569 & 0.643 & 0.652 & 0.651 & 0.657 & 0.433 \\
\hline & $(0.016)$ & $(0.018)$ & $(0.014)$ & 0.0163 & $(0.017)$ & $(0.018)$ & $(0.017)$ & 0.00653 \\
\hline Cohort N & 64 & 64 & 64 & 64 & 64 & 64 & 64 & 64 \\
\hline Individual $\mathrm{N}$ & 2106760 & 2106760 & 2106760 & 2106760 & 2106760 & 2106760 & 2106760 & 2106760 \\
\hline $\mathrm{N}$ & 12429152 & 12429152 & 12429152 & 12429152 & 12429152 & 12429152 & 12429152 & 12429152 \\
\hline
\end{tabular}

Standard errors in parentheses

Note: all estimates statistically significant, $(\mathrm{p}<0.001)$ 
Table A.3. Repeated-measures linear regression implementing the method of generalized estimation equations (GEE), two-way cohort $\mathrm{X}$ age interaction effects for men's income

Baseline model

\begin{tabular}{|c|c|c|c|c|c|c|c|}
\hline & $1920-29$ & 1930-39 & $1940-49$ & $1950-59$ & $1960-69$ & $1970-79$ & $1980-89$ \\
\hline $20-24$ & & & $\begin{array}{l}13973.4 \\
(29.363)\end{array}$ & $\begin{array}{c}13339.3 \\
(21.245)\end{array}$ & $\begin{array}{r}17011.5 \\
(23.571)\end{array}$ & $\begin{array}{c}16355.7 \\
(24.291)\end{array}$ & $\begin{array}{r}17149.0 \\
(34.562)\end{array}$ \\
\hline $25-29$ & & & $\begin{array}{l}18945.7 \\
(24.785)\end{array}$ & $\begin{array}{c}18561.4 \\
(21.977)\end{array}$ & $\begin{array}{l}20868.6 \\
(20.746)\end{array}$ & $\begin{array}{l}24051.4 \\
(27.016)\end{array}$ & $\begin{array}{l}24506.8 \\
(43.585)\end{array}$ \\
\hline $30-34$ & & $\begin{array}{l}18676.6 \\
(39.625)\end{array}$ & $\begin{array}{l}21534.0 \\
(26.972)\end{array}$ & $\begin{array}{l}23451.3 \\
(24.659)\end{array}$ & $\begin{array}{l}23818.8 \\
(25.485)\end{array}$ & $\begin{array}{l}30434.2 \\
(35.602)\end{array}$ & $\begin{array}{l}30135.3 \\
(54.758)\end{array}$ \\
\hline $35-39$ & & $\begin{array}{l}20856.5 \\
(33.250)\end{array}$ & $\begin{array}{l}23592.1 \\
(29.375)\end{array}$ & $\begin{array}{l}25051.2 \\
(26.515)\end{array}$ & $\begin{array}{l}28126.9 \\
(32.941)\end{array}$ & $\begin{array}{l}34029.4 \\
(43.000)\end{array}$ & $\begin{array}{l}33379.5 \\
(64.738)\end{array}$ \\
\hline $40-44$ & $\begin{array}{c}17394.1 \\
(39.874)\end{array}$ & $\begin{array}{l}21501.9 \\
(33.769)\end{array}$ & $\begin{array}{l}26520.8 \\
(31.165)\end{array}$ & $\begin{array}{l}25062.9 \\
(29.477)\end{array}$ & $\begin{array}{l}31355.6 \\
(39.801)\end{array}$ & $\begin{array}{l}35844.4 \\
(49.267)\end{array}$ & \\
\hline $45-49$ & $\begin{array}{l}18611.4 \\
(33.978)\end{array}$ & $\begin{array}{l}21612.0 \\
(34.025)\end{array}$ & $\begin{array}{l}25491.4 \\
(31.454)\end{array}$ & $\begin{array}{l}26936.7 \\
(33.968)\end{array}$ & $\begin{array}{l}32519.8 \\
(43.505)\end{array}$ & $\begin{array}{l}37234.4 \\
(71.007)\end{array}$ & \\
\hline $50-54$ & $\begin{array}{c}17573.1 \\
(32.941)\end{array}$ & $\begin{array}{l}22939.6 \\
(33.356)\end{array}$ & $\begin{array}{l}24199.2 \\
(32.468)\end{array}$ & $\begin{array}{l}28052.6 \\
(37.576)\end{array}$ & $\begin{array}{l}32152.8 \\
(45.865)\end{array}$ & & \\
\hline $55-59$ & $\begin{array}{l}16117.3 \\
(29.725)\end{array}$ & $\begin{array}{l}20957.9 \\
(29.007)\end{array}$ & $\begin{array}{l}23824.8 \\
(32.360)\end{array}$ & $\begin{array}{l}27524.0 \\
(37.605)\end{array}$ & $\begin{array}{c}31066.3 \\
(59.671)\end{array}$ & & \\
\hline $60-64$ & $\begin{array}{l}15380.3 \\
(24.317)\end{array}$ & $\begin{array}{l}18444.0 \\
(23.396)\end{array}$ & $\begin{array}{l}23493.6 \\
(28.148)\end{array}$ & $\begin{array}{l}26214.3 \\
(33.702)\end{array}$ & & & \\
\hline \multicolumn{8}{|c|}{ Goldthorpe-Erikson-Portocarero (EGP) class scheme } \\
\hline & 1920-29 & 1930-39 & 1940-49 & 1950-59 & 1960-69 & 1970-79 & $1980-89$ \\
\hline $20-24$ & & & $\begin{array}{c}14221.677 \\
(27.993)\end{array}$ & $\begin{array}{c}13542.883 \\
(20.218)\end{array}$ & $\begin{array}{c}16933.334 \\
(22.628)\end{array}$ & $\begin{array}{c}16267.826 \\
(23.564)\end{array}$ & $\begin{array}{c}17390.018 \\
(34.872)\end{array}$ \\
\hline $25-29$ & & & $\begin{array}{c}18704.620 \\
(22.326)\end{array}$ & $\begin{array}{c}18283.588 \\
(20.422)\end{array}$ & $\begin{array}{c}20660.300 \\
(19.803)\end{array}$ & $\begin{array}{c}23702.391 \\
(25.677)\end{array}$ & $\begin{array}{c}24469.038 \\
(42.585)\end{array}$ \\
\hline $30-34$ & & $\begin{array}{c}19399.332 \\
(38.046)\end{array}$ & $\begin{array}{c}20959.115 \\
(24.021)\end{array}$ & $\begin{array}{c}23026.713 \\
(22.485)\end{array}$ & $\begin{array}{c}23473.241 \\
(23.599)\end{array}$ & $\begin{array}{c}29449.659 \\
(32.326)\end{array}$ & $\begin{array}{c}29315.196 \\
(50.613)\end{array}$ \\
\hline $35-39$ & & $\begin{array}{c}21582.293 \\
(30.778)\end{array}$ & $\begin{array}{c}22884.379 \\
(26.042)\end{array}$ & $\begin{array}{c}24801.423 \\
(24.085)\end{array}$ & $\begin{array}{c}27701.398 \\
(29.976)\end{array}$ & $\begin{array}{c}32721.274 \\
(38.412)\end{array}$ & $\begin{array}{c}31454.728 \\
(57.128)\end{array}$ \\
\hline $40-44$ & $\begin{array}{c}19299.062 \\
(41.069)\end{array}$ & $\begin{array}{c}22076.579 \\
(31.331)\end{array}$ & $\begin{array}{c}26032.968 \\
(27.700)\end{array}$ & $\begin{array}{c}24914.302 \\
(26.731)\end{array}$ & $\begin{array}{c}30936.715 \\
(36.156)\end{array}$ & $\begin{array}{c}34111.000 \\
(43.471)\end{array}$ & \\
\hline $45-49$ & $\begin{array}{c}20455.456 \\
(33.967)\end{array}$ & $\begin{array}{c}22113.940 \\
(31.324)\end{array}$ & $\begin{array}{c}25363.510 \\
(28.285)\end{array}$ & $\begin{array}{c}26901.544 \\
(31.054)\end{array}$ & $\begin{array}{c}32147.661 \\
(39.623)\end{array}$ & $\begin{array}{c}35064.866 \\
(63.298)\end{array}$ & \\
\hline $50-54$ & $\begin{array}{c}19184.914 \\
(32.849)\end{array}$ & $\begin{array}{c}23684.115 \\
(30.877)\end{array}$ & $\begin{array}{c}24211.677 \\
(29.427)\end{array}$ & $\begin{array}{c}28151.587 \\
(34.679)\end{array}$ & $\begin{array}{c}31619.926 \\
(41.661)\end{array}$ & & \\
\hline
\end{tabular}




\begin{tabular}{|c|c|c|c|c|c|c|c|}
\hline $55-59$ & $\begin{array}{c}17558.089 \\
(29.294)\end{array}$ & $\begin{array}{c}21799.845 \\
(27.039)\end{array}$ & $\begin{array}{c}23905.480 \\
(29.585)\end{array}$ & $\begin{array}{c}27697.331 \\
(34.801)\end{array}$ & $\begin{array}{c}30403.792 \\
(55.379)\end{array}$ & & \\
\hline $60-64$ & $\begin{array}{c}16827.799 \\
(24.107)\end{array}$ & $\begin{array}{c}19168.698 \\
(21.223)\end{array}$ & $\begin{array}{c}23529.066 \\
(25.451)\end{array}$ & $\begin{array}{c}26223.302 \\
(31.028)\end{array}$ & & & \\
\hline \multicolumn{8}{|c|}{ Years of education } \\
\hline & 1920-29 & 1930-39 & $1940-49$ & 1950-59 & $1960-69$ & 1970-79 & $1980-89$ \\
\hline $20-24$ & & & $\begin{array}{c}15268.364 \\
(31.532)\end{array}$ & $\begin{array}{c}13875.909 \\
(21.673)\end{array}$ & $\begin{array}{c}16777.959 \\
(22.913)\end{array}$ & $\begin{array}{c}15570.591 \\
(22.943)\end{array}$ & $\begin{array}{c}16710.422 \\
(34.043)\end{array}$ \\
\hline $25-29$ & & & $\begin{array}{c}20215.160 \\
(25.343)\end{array}$ & $\begin{array}{c}18724.550 \\
(21.837)\end{array}$ & $\begin{array}{c}19913.766 \\
(19.949)\end{array}$ & $\begin{array}{c}21630.160 \\
(24.414)\end{array}$ & $\begin{array}{c}21962.578 \\
(40.013)\end{array}$ \\
\hline $30-34$ & & $\begin{array}{c}20651.915 \\
(41.927)\end{array}$ & $\begin{array}{c}22650.176 \\
(26.897)\end{array}$ & $\begin{array}{c}23267.366 \\
(23.329)\end{array}$ & $\begin{array}{c}22359.289 \\
(22.901)\end{array}$ & $\begin{array}{c}26760.696 \\
(30.498)\end{array}$ & $\begin{array}{c}26298.157 \\
(47.101)\end{array}$ \\
\hline $35-39$ & & $\begin{array}{c}22978.373 \\
(34.224)\end{array}$ & $\begin{array}{c}24652.115 \\
(28.889)\end{array}$ & $\begin{array}{c}24748.467 \\
(24.557)\end{array}$ & $\begin{array}{c}26188.675 \\
(28.774)\end{array}$ & $\begin{array}{c}29584.331 \\
(35.866)\end{array}$ & $\begin{array}{c}28786.592 \\
(54.162)\end{array}$ \\
\hline $40-44$ & $\begin{array}{c}19785.065 \\
(43.614)\end{array}$ & $\begin{array}{c}23633.399 \\
(34.888)\end{array}$ & $\begin{array}{c}27677.642 \\
(30.086)\end{array}$ & $\begin{array}{c}24675.046 \\
(27.061)\end{array}$ & $\begin{array}{c}29045.122 \\
(34.467)\end{array}$ & $\begin{array}{c}30951.004 \\
(40.707)\end{array}$ & \\
\hline $45-49$ & $\begin{array}{c}21100.804 \\
(36.533)\end{array}$ & $\begin{array}{c}23718.805 \\
(35.072)\end{array}$ & $\begin{array}{c}26613.598 \\
(30.447)\end{array}$ & $\begin{array}{c}26451.653 \\
(31.091)\end{array}$ & $\begin{array}{c}30002.060 \\
(37.618)\end{array}$ & $\begin{array}{c}32102.856 \\
(59.309)\end{array}$ & \\
\hline $50-54$ & $\begin{array}{c}19904.971 \\
(35.505)\end{array}$ & $\begin{array}{c}25193.444 \\
(34.010)\end{array}$ & $\begin{array}{c}25247.625 \\
(31.638)\end{array}$ & $\begin{array}{c}27498.635 \\
(34.481)\end{array}$ & $\begin{array}{c}29598.142 \\
(39.860)\end{array}$ & & \\
\hline $55-59$ & $\begin{array}{c}18249.592 \\
(31.854)\end{array}$ & $\begin{array}{c}23049.963 \\
(29.284)\end{array}$ & $\begin{array}{c}24844.000 \\
(31.366)\end{array}$ & $\begin{array}{c}26941.440 \\
(34.522)\end{array}$ & $\begin{array}{c}28680.646 \\
(53.356)\end{array}$ & & \\
\hline $60-64$ & $\begin{array}{c}17430.691 \\
(25.599)\end{array}$ & $\begin{array}{c}20289.841 \\
(23.127)\end{array}$ & $\begin{array}{c}24484.401 \\
(26.602)\end{array}$ & $\begin{array}{c}25629.434 \\
(30.641)\end{array}$ & & & \\
\hline \multicolumn{8}{|c|}{ Number of children } \\
\hline & 1920-29 & 1930-39 & $1940-49$ & $1950-59$ & $1960-69$ & 1970-79 & 1980-89 \\
\hline $20-24$ & & & $\begin{array}{c}13812.292 \\
(29.258)\end{array}$ & $\begin{array}{c}13187.295 \\
(21.160)\end{array}$ & $\begin{array}{c}17010.376 \\
(23.720)\end{array}$ & $\begin{array}{c}16463.906 \\
(24.572)\end{array}$ & $\begin{array}{c}17380.283 \\
(35.086)\end{array}$ \\
\hline $25-29$ & & & $\begin{array}{c}18955.778 \\
(24.916)\end{array}$ & $\begin{array}{c}18629.896 \\
(22.162)\end{array}$ & $\begin{array}{c}20921.688 \\
(20.857)\end{array}$ & $\begin{array}{c}24299.092 \\
(27.346)\end{array}$ & $\begin{array}{c}24793.045 \\
(44.025)\end{array}$ \\
\hline $30-34$ & & $\begin{array}{c}18376.717 \\
(39.085)\end{array}$ & $\begin{array}{c}21441.875 \\
(26.826)\end{array}$ & $\begin{array}{c}23292.509 \\
(24.481)\end{array}$ & $\begin{array}{c}23720.336 \\
(25.350)\end{array}$ & $\begin{array}{c}30438.125 \\
(35.436)\end{array}$ & $\begin{array}{c}30195.465 \\
(54.490)\end{array}$ \\
\hline $35-39$ & & $\begin{array}{c}20448.143 \\
(32.744)\end{array}$ & $\begin{array}{c}23354.846 \\
(29.033)\end{array}$ & $\begin{array}{c}24739.174 \\
(26.183)\end{array}$ & $\begin{array}{c}27864.513 \\
(32.562)\end{array}$ & $\begin{array}{c}33776.670 \\
(42.460)\end{array}$ & $\begin{array}{c}33383.556 \\
(64.243)\end{array}$ \\
\hline $40-44$ & $\begin{array}{c}16902.703 \\
(38.942)\end{array}$ & $\begin{array}{c}21142.832 \\
(33.264)\end{array}$ & $\begin{array}{c}26227.446 \\
(30.745)\end{array}$ & $\begin{array}{c}24781.813 \\
(29.040)\end{array}$ & $\begin{array}{c}31064.096 \\
(39.264)\end{array}$ & $\begin{array}{c}35592.321 \\
(48.605)\end{array}$ & \\
\hline $45-49$ & 18284.088 & 21460.166 & 25359.250 & 26820.784 & 32388.637 & 37191.041 & \\
\hline
\end{tabular}




\begin{tabular}{|c|c|c|c|c|c|c|c|}
\hline & (33.461) & (33.708) & (31.117) & (33.581) & (43.009) & $(70.429)$ & \\
\hline $50-54$ & $\begin{array}{c}17545.662 \\
(32.828)\end{array}$ & $\begin{array}{c}23043.899 \\
(33.396)\end{array}$ & $\begin{array}{c}24380.016 \\
(32.618)\end{array}$ & $\begin{array}{c}28265.777 \\
(37.684)\end{array}$ & $\begin{array}{c}32379.107 \\
(45.891)\end{array}$ & & \\
\hline $55-59$ & $\begin{array}{c}16325.865 \\
(30.107)\end{array}$ & $\begin{array}{c}21288.044 \\
(29.494)\end{array}$ & $\begin{array}{c}24289.716 \\
(33.162)\end{array}$ & $\begin{array}{c}28055.332 \\
(38.472)\end{array}$ & $\begin{array}{c}31684.778 \\
(60.886)\end{array}$ & & \\
\hline $60-64$ & $\begin{array}{c}15709.989 \\
(24.934) \\
\end{array}$ & $\begin{array}{c}18906.341 \\
(24.225) \\
\end{array}$ & $\begin{array}{c}24135.872 \\
(29.410) \\
\end{array}$ & $\begin{array}{c}26931.122 \\
(35.108) \\
\end{array}$ & & & \\
\hline \multicolumn{8}{|c|}{ Income transfers } \\
\hline & $1920-29$ & 1930-39 & $1940-49$ & $1950-59$ & $1960-69$ & $1970-79$ & $1980-89$ \\
\hline $20-24$ & & & $\begin{array}{c}13827.335 \\
(30.552)\end{array}$ & $\begin{array}{c}13192.371 \\
(22.916)\end{array}$ & $\begin{array}{c}16888.558 \\
(24.625)\end{array}$ & $\begin{array}{c}16280.471 \\
(24.539)\end{array}$ & $\begin{array}{c}17039.019 \\
(34.922)\end{array}$ \\
\hline $25-29$ & & & $\begin{array}{c}18743.433 \\
(27.711)\end{array}$ & $\begin{array}{c}18377.450 \\
(24.623)\end{array}$ & $\begin{array}{c}20799.536 \\
(21.099)\end{array}$ & $\begin{array}{c}23889.152 \\
(28.638)\end{array}$ & $\begin{array}{c}24333.093 \\
(44.486)\end{array}$ \\
\hline $30-34$ & & $\begin{array}{c}18453.873 \\
(41.633)\end{array}$ & $\begin{array}{c}21315.846 \\
(30.190)\end{array}$ & $\begin{array}{c}23313.908 \\
(26.042)\end{array}$ & $\begin{array}{c}23741.287 \\
(25.744)\end{array}$ & $\begin{array}{c}30235.781 \\
(37.374)\end{array}$ & $\begin{array}{c}29982.843 \\
(55.037)\end{array}$ \\
\hline $35-39$ & & $\begin{array}{c}20633.587 \\
(35.848)\end{array}$ & $\begin{array}{c}23385.959 \\
(32.114)\end{array}$ & $\begin{array}{c}25036.584 \\
(26.522)\end{array}$ & $\begin{array}{c}28004.776 \\
(33.568)\end{array}$ & $\begin{array}{c}33855.862 \\
(43.968)\end{array}$ & $\begin{array}{c}33261.643 \\
(64.576)\end{array}$ \\
\hline
\end{tabular}

$\begin{array}{lllllll}40-44 & 17158.505 & 21299.984 & 26470.853 & 25041.241 & 31228.956 & 35725.790\end{array}$

$\begin{array}{llllll}(42.062) & (35.877) & (31.446) & (29.383) & (40.268) & \text { (49.408) }\end{array}$

$\begin{array}{lllllll}45-49 & 18423.236 & 21465.291 & 25585.371 & 26904.179 & 32436.197 & 37158.572\end{array}$

$\begin{array}{llllll}(35.726) & (35.080) & (32.037) & (33.873) & (43.466) & \text { (70.632) }\end{array}$

$\begin{array}{llllll}50-54 & 17460.276 & 23004.349 & 24326.530 & 28080.624 & 32169.762\end{array}$

$\begin{array}{lllll}(33.541) & (33.768) & (33.342) & (37.478) & \text { (45.614) }\end{array}$

$\begin{array}{llllll}55-59 & 16169.129 & 21402.654 & 24179.528 & 27702.761 & 31209.991\end{array}$

$\begin{array}{lllll}(30.047) & (40.957) & (38.712) & (39.304) & (60.288)\end{array}$

60-64 $\quad 15807.506 \quad 19262.813 \quad 24349.085 \quad 26842.669$

$\begin{array}{llll}(37.142) & (58.164) & (61.132) & (52.723)\end{array}$

\begin{tabular}{|c|c|c|c|c|c|c|c|}
\hline \multicolumn{8}{|c|}{ Months of unemployment } \\
\hline & $1920-29$ & 1930-39 & $1940-49$ & $1950-59$ & $1960-69$ & 1970-79 & $1980-89$ \\
\hline $20-24$ & & & $\begin{array}{c}13104.253 \\
(27.325)\end{array}$ & $\begin{array}{c}12578.055 \\
(19.826)\end{array}$ & $\begin{array}{c}16825.506 \\
(22.809)\end{array}$ & $\begin{array}{c}17259.414 \\
(24.541)\end{array}$ & $\begin{array}{c}16992.981 \\
(33.760)\end{array}$ \\
\hline $25-29$ & & & $\begin{array}{c}17916.694 \\
(23.344)\end{array}$ & $\begin{array}{c}17667.156 \\
(20.720)\end{array}$ & $\begin{array}{c}22050.141 \\
(20.540)\end{array}$ & $\begin{array}{c}24424.715 \\
(25.701)\end{array}$ & $\begin{array}{c}24926.857 \\
(42.593)\end{array}$ \\
\hline 30-34 & & $\begin{array}{c}17476.784 \\
(37.122)\end{array}$ & $\begin{array}{c}20398.839 \\
(25.456)\end{array}$ & $\begin{array}{c}22988.635 \\
(23.619)\end{array}$ & $\begin{array}{c}25205.282 \\
(24.675)\end{array}$ & $\begin{array}{c}30708.679 \\
(33.663)\end{array}$ & $\begin{array}{c}30990.063 \\
(52.426)\end{array}$ \\
\hline $35-39$ & & $\begin{array}{c}19689.203 \\
(31.408)\end{array}$ & $\begin{array}{c}22475.655 \\
(27.739)\end{array}$ & $\begin{array}{c}25867.829 \\
(25.720)\end{array}$ & $\begin{array}{c}28780.359 \\
(31.069)\end{array}$ & $\begin{array}{c}34610.884 \\
(40.983)\end{array}$ & $\begin{array}{c}33221.086 \\
(60.603)\end{array}$ \\
\hline
\end{tabular}

$\begin{array}{lllllll}40-44 & 16424.406 & 20349.137 & 26039.368 & 26226.753 & 31880.384 & 36206.062\end{array}$ 


\begin{tabular}{|c|c|c|c|c|c|c|c|}
\hline & (37.693) & (31.944) & (29.795) & (28.680) & $(38.022)$ & (46.928) & \\
\hline $45-49$ & $\begin{array}{c}17595.017 \\
(32.145)\end{array}$ & $\begin{array}{c}20560.151 \\
(32.241)\end{array}$ & $\begin{array}{c}26177.492 \\
(30.651)\end{array}$ & $\begin{array}{c}27637.815 \\
(32.487)\end{array}$ & $\begin{array}{c}33383.984 \\
(42.301)\end{array}$ & $\begin{array}{c}36780.885 \\
(67.455)\end{array}$ & \\
\hline $50-54$ & $\begin{array}{c}16620.606 \\
(31.178)\end{array}$ & $\begin{array}{c}22412.977 \\
(32.120)\end{array}$ & $\begin{array}{c}25033.997 \\
(31.785)\end{array}$ & $\begin{array}{c}28680.827 \\
(36.491)\end{array}$ & $\begin{array}{c}32967.053 \\
(44.715)\end{array}$ & & \\
\hline $55-59$ & $\begin{array}{c}15297.051 \\
(28.258)\end{array}$ & $\begin{array}{c}21572.470 \\
(29.452)\end{array}$ & $\begin{array}{c}25086.051 \\
(32.829)\end{array}$ & $\begin{array}{c}28640.722 \\
(37.966)\end{array}$ & $\begin{array}{c}31649.743 \\
(58.524)\end{array}$ & & \\
\hline $60-64$ & $\begin{array}{c}14704.101 \\
(23.380)\end{array}$ & $\begin{array}{c}18736.168 \\
(23.968)\end{array}$ & $\begin{array}{c}24264.582 \\
(28.765)\end{array}$ & $\begin{array}{c}27470.778 \\
(34.575)\end{array}$ & & & \\
\hline \multicolumn{8}{|c|}{ Age structure } \\
\hline & 1920-29 & 1930-39 & $1940-49$ & 1950-59 & 1960-69 & 1970-79 & 1980-89 \\
\hline $20-24$ & & & $\begin{array}{c}14903.288 \\
(33.305)\end{array}$ & $\begin{array}{c}12916.390 \\
(21.398)\end{array}$ & $\begin{array}{c}15560.655 \\
(29.173)\end{array}$ & $\begin{array}{c}13179.483 \\
(43.364)\end{array}$ & $\begin{array}{c}12890.596 \\
(56.977)\end{array}$ \\
\hline $25-29$ & & & $\begin{array}{c}20284.029 \\
(32.111)\end{array}$ & $\begin{array}{c}17970.986 \\
(22.776)\end{array}$ & $\begin{array}{c}19097.395 \\
(30.100)\end{array}$ & $\begin{array}{c}19352.650 \\
(62.019)\end{array}$ & $\begin{array}{c}18422.563 \\
(79.465)\end{array}$ \\
\hline $30-34$ & & $\begin{array}{c}22935.780 \\
(80.733)\end{array}$ & $\begin{array}{c}23075.615 \\
(36.366)\end{array}$ & $\begin{array}{c}22704.645 \\
(26.001)\end{array}$ & $\begin{array}{c}21798.425 \\
(35.150)\end{array}$ & $\begin{array}{c}24494.321 \\
(78.590)\end{array}$ & $\begin{array}{c}22653.585 \\
(98.095)\end{array}$ \\
\hline $35-39$ & & $\begin{array}{c}25726.007 \\
(84.011)\end{array}$ & $\begin{array}{c}25278.929 \\
(39.292)\end{array}$ & $\begin{array}{c}24254.517 \\
(27.845)\end{array}$ & $\begin{array}{c}25739.417 \\
(43.426)\end{array}$ & $\begin{array}{c}27388.320 \\
(89.235)\end{array}$ & $\begin{array}{r}25093.443 \\
(109.956)\end{array}$ \\
\hline $40-44$ & $\begin{array}{c}22347.766 \\
(92.607)\end{array}$ & $\begin{array}{c}26542.775 \\
(87.150)\end{array}$ & $\begin{array}{c}28416.565 \\
(42.705)\end{array}$ & $\begin{array}{c}24266.020 \\
(30.407)\end{array}$ & $\begin{array}{c}28693.695 \\
(50.378)\end{array}$ & $\begin{array}{c}28892.942 \\
(95.074)\end{array}$ & \\
\hline $45-49$ & $\begin{array}{c}23930.709 \\
(93.563)\end{array}$ & $\begin{array}{c}26676.693 \\
(86.970)\end{array}$ & $\begin{array}{c}27315.473 \\
(43.237)\end{array}$ & $\begin{array}{c}26079.822 \\
(34.812)\end{array}$ & $\begin{array}{c}29758.680 \\
(53.969)\end{array}$ & $\begin{array}{l}30273.587 \\
(107.081)\end{array}$ & \\
\hline $50-54$ & $\begin{array}{c}22599.702 \\
(88.933)\end{array}$ & $\begin{array}{c}28314.515 \\
(91.070)\end{array}$ & $\begin{array}{c}25931.077 \\
(43.238)\end{array}$ & $\begin{array}{c}27160.058 \\
(38.272)\end{array}$ & $\begin{array}{c}29439.448 \\
(55.305)\end{array}$ & & \\
\hline $55-59$ & $\begin{array}{c}20727.306 \\
(81.022)\end{array}$ & $\begin{array}{c}25869.673 \\
(83.023)\end{array}$ & $\begin{array}{c}25529.194 \\
(42.759)\end{array}$ & $\begin{array}{c}26648.137 \\
(38.278)\end{array}$ & $\begin{array}{c}28516.190 \\
(65.158)\end{array}$ & & \\
\hline $60-64$ & $\begin{array}{c}19779.186 \\
(75.091)\end{array}$ & $\begin{array}{c}22766.235 \\
(72.063)\end{array}$ & $\begin{array}{c}25174.044 \\
(38.861)\end{array}$ & $\begin{array}{c}25386.999 \\
(34.426)\end{array}$ & & & \\
\hline \multicolumn{8}{|c|}{ Full model } \\
\hline & 1920-29 & 1930-39 & $1940-49$ & 1950-59 & 1960-69 & 1970-79 & 1980-89 \\
\hline $20-24$ & & & $\begin{array}{c}14342.273 \\
(29.507)\end{array}$ & $\begin{array}{c}12342.245 \\
(19.061)\end{array}$ & $\begin{array}{c}15280.807 \\
(25.153)\end{array}$ & $\begin{array}{c}14076.679 \\
(37.533)\end{array}$ & $\begin{array}{c}13564.590 \\
(49.654)\end{array}$ \\
\hline $25-29$ & & & $\begin{array}{c}19235.790 \\
(27.114)\end{array}$ & $\begin{array}{c}16918.857 \\
(20.166)\end{array}$ & $\begin{array}{c}19688.485 \\
(26.209)\end{array}$ & $\begin{array}{c}19082.468 \\
(48.559)\end{array}$ & $\begin{array}{c}18663.775 \\
(65.598)\end{array}$ \\
\hline $30-34$ & & $\begin{array}{c}21848.141 \\
(63.466)\end{array}$ & $\begin{array}{c}21430.954 \\
(29.745)\end{array}$ & $\begin{array}{c}21619.643 \\
(22.152)\end{array}$ & $\begin{array}{c}22165.094 \\
(29.160)\end{array}$ & $\begin{array}{c}23237.378 \\
(58.954)\end{array}$ & $\begin{array}{c}22403.779 \\
(77.702)\end{array}$ \\
\hline
\end{tabular}




\begin{tabular}{lccccccc}
$35-39$ & & 24588.427 & 23399.163 & 24476.459 & 25060.925 & 25873.073 & 23346.302 \\
& & $(64.985)$ & $(31.507)$ & $(23.481)$ & $(34.093)$ & $(66.679)$ & $(81.838)$ \\
$40-44$ & 22774.687 & 25354.095 & 27448.441 & 24983.692 & 27797.612 & 26929.013 & \\
& $(78.104)$ & $(67.373)$ & $(34.119)$ & $(25.374)$ & $(39.590)$ & $(69.931)$ & \\
$45-49$ & 24507.382 & 25844.242 & 28275.758 & 26563.419 & 29371.118 & 27638.637 & \\
& $(77.554)$ & $(67.607)$ & $(36.147)$ & $(28.634)$ & $(43.325)$ & $(77.757)$ & \\
$50-54$ & 23450.616 & 28878.580 & 27591.547 & 28028.901 & 29312.801 & \\
& $(74.689)$ & $(73.905)$ & $(37.346)$ & $(32.718)$ & $(45.015)$ & \\
$55-59$ & 21961.593 & 28607.855 & 28164.008 & 28489.371 & 28615.575 & & \\
& $(69.256)$ & $(74.454)$ & $(40.293)$ & $(35.125)$ & $(56.182)$ & & \\
$60-64$ & 21580.427 & 25295.047 & 27580.737 & 27617.469 & & & \\
& $(67.897)$ & $(70.199)$ & $(44.156)$ & $(36.483)$ & & & \\
\hline $\mathrm{N}$ & 13384065 & 13384065 & 13384065 & 13384065 & 13384065 & 13384065 & 13384065 \\
\hline
\end{tabular}

Standard errors in parentheses

Note: All estimates statistically significant, $p<0.001$ 
Table A.4. Repeated-measures linear regression implementing the method of generalized estimation equations (GEE), two-way cohort $\mathrm{X}$ age interaction effects for women's income

Baseline model

\begin{tabular}{lccccccc}
\hline & $1920-29$ & $1930-39$ & $1940-49$ & $1950-59$ & $1960-69$ & $1970-79$ & $1980-89$ \\
\hline $20-24$ & & & 9676.4 & 10768.8 & 14035.2 & 13563.9 & 14020.0 \\
& & & $(22.971)$ & $(16.244)$ & $(17.633)$ & $(18.396)$ & $(24.503)$ \\
$25-29$ & & & 10808.4 & 12583.3 & 17093.7 & 18667.7 & 20157.8 \\
& & & $(19.953)$ & $(18.000)$ & $(15.660)$ & $(20.325)$ & $(33.659)$ \\
$30-34$ & & 9807.5 & 11577.3 & 16282.9 & 18488.8 & 22536.8 & 23851.7 \\
& & $(31.077)$ & $(21.030)$ & $(19.990)$ & $(17.977)$ & $(24.677)$ & $(39.826)$ \\
$35-39$ & & 10475.1 & 14686.8 & 19043.7 & 21402.3 & 26189.7 & 25569.7 \\
& & $(25.845)$ & $(22.502)$ & $(20.131)$ & $(22.779)$ & $(29.411)$ & $(46.089)$ \\
$40-44$ & 8421.4 & 11856.4 & 18700.8 & 20640.7 & 25500.4 & 29013.8 & \\
& $(30.381)$ & $(25.303)$ & $(23.857)$ & $(21.972)$ & $(28.007)$ & $(34.690)$ & \\
$45-49$ & 8819.6 & 14095.1 & 20111.7 & 22981.5 & 28464.3 & 31287.6 & \\
& $(25.298)$ & $(25.263)$ & $(24.182)$ & $(25.176)$ & $(31.678)$ & $(51.414)$ & \\
$50-54$ & 9152.4 & 16302.0 & 20265.3 & 24948.6 & 29181.2 & & \\
& $(23.787)$ & $(26.355)$ & $(24.956)$ & $(28.282)$ & $(33.719)$ & & \\
$55-59$ & 9901.4 & 16195.7 & 20263.1 & 25573.7 & 28908.3 & & \\
& $(22.382)$ & $(23.744)$ & $(24.467)$ & $(28.767)$ & $(44.177)$ & & \\
$60-64$ & 10668.7 & 14355.3 & 19420.9 & 24263.3 & & & \\
& $(18.428)$ & $(17.024)$ & $(20.444)$ & $(25.944)$ & & & \\
\hline
\end{tabular}

Goldthorpe-Erikson-Portocarero (EGP) class scheme

\begin{tabular}{lccccccc}
\hline & $1920-29$ & $1930-39$ & $1940-49$ & $1950-59$ & $1960-69$ & $1970-79$ & $1980-89$ \\
\hline $20-24$ & & & 9856.165 & 10625.590 & 13728.966 & 13356.533 & 13974.455 \\
& & $(22.072)$ & $(15.066)$ & $(16.737)$ & $(17.528)$ & $(23.966)$ \\
$25-29$ & & 10922.738 & 12280.023 & 16745.836 & 18133.205 & 19646.177 \\
& & $(18.490)$ & $(16.757)$ & $(14.812)$ & $(18.764)$ & $(31.162)$ \\
$30-34$ & & 10657.815 & 11661.734 & 16032.401 & 18094.423 & 21589.894 & 22689.175 \\
& & $(30.798)$ & $(19.602)$ & $(18.900)$ & $(16.708)$ & $(22.150)$ & $(35.223)$ \\
$35-39$ & & 11397.661 & 14755.362 & 19002.097 & 20842.359 & 24885.440 & 23628.034 \\
& & $(24.492)$ & $(21.220)$ & $(19.087)$ & $(20.788)$ & $(25.916)$ & $(39.356)$ \\
$40-44$ & 9939.163 & 12860.310 & 18984.297 & 20513.361 & 24663.821 & 27129.619 & \\
& $(31.997)$ & $(23.938)$ & $(22.663)$ & $(20.193)$ & $(25.118)$ & $(29.874)$ & \\
$45-49$ & 10368.844 & 15182.057 & 20632.229 & 22655.197 & 27309.485 & 28793.883 & \\
& $(25.314)$ & $(24.373)$ & $(22.906)$ & $(22.754)$ & $(27.919)$ & $(44.463)$ & \\
$50-54$ & 10793.137 & 17623.199 & 20708.523 & 24483.032 & 27698.088 \\
& $(24.028)$ & $(25.969)$ & $(23.119)$ & $(25.439)$ & $(29.335)$ & &
\end{tabular}


$\begin{array}{cccccc}55-59 & 11718.213 & 17646.494 & 20550.010 & 24986.966 & 27173.474 \\ & (23.322) & (23.751) & (22.471) & (25.596) & (38.962) \\ 60-64 & 12694.268 & 15625.163 & 19602.499 & 23523.414 & \\ & (20.031) & (16.876) & (18.793) & (23.052) & \\ & & & & Y & \end{array}$

\begin{tabular}{|c|c|c|c|c|c|c|c|}
\hline \multicolumn{8}{|c|}{ Years of education } \\
\hline & $1920-29$ & 1930-39 & $1940-49$ & $1950-59$ & $1960-69$ & $1970-79$ & $1980-89$ \\
\hline $20-24$ & & & $\begin{array}{c}10704.156 \\
(24.901)\end{array}$ & $\begin{array}{c}11219.048 \\
(16.640)\end{array}$ & $\begin{array}{c}13662.403 \\
(16.839)\end{array}$ & $\begin{array}{c}12624.788 \\
(17.011)\end{array}$ & $\begin{array}{c}13196.065 \\
(23.069)\end{array}$ \\
\hline $25-29$ & & & $\begin{array}{c}11803.453 \\
(21.075)\end{array}$ & $\begin{array}{c}12803.831 \\
(17.751)\end{array}$ & $\begin{array}{c}16092.180 \\
(14.547)\end{array}$ & $\begin{array}{c}16219.172 \\
(17.375)\end{array}$ & $\begin{array}{c}17267.380 \\
(28.504)\end{array}$ \\
\hline $30-34$ & & $\begin{array}{c}11244.362 \\
(34.811)\end{array}$ & $\begin{array}{c}12569.943 \\
(22.239)\end{array}$ & $\begin{array}{c}16409.732 \\
(19.392)\end{array}$ & $\begin{array}{c}17093.214 \\
(15.930)\end{array}$ & $\begin{array}{c}19116.084 \\
(20.436)\end{array}$ & $\begin{array}{c}19889.761 \\
(32.105)\end{array}$ \\
\hline $35-39$ & & $\begin{array}{c}11992.014 \\
(28.753)\end{array}$ & $\begin{array}{c}15875.042 \\
(23.684)\end{array}$ & $\begin{array}{c}19058.314 \\
(19.314)\end{array}$ & $\begin{array}{c}19527.635 \\
(19.744)\end{array}$ & $\begin{array}{c}21894.198 \\
(23.903)\end{array}$ & $\begin{array}{c}21071.037 \\
(36.567)\end{array}$ \\
\hline $40-44$ & $\begin{array}{c}9992.149 \\
(35.441)\end{array}$ & $\begin{array}{c}13544.019 \\
(28.079)\end{array}$ & $\begin{array}{c}20167.411 \\
(24.748)\end{array}$ & $\begin{array}{c}20452.386 \\
(20.624)\end{array}$ & $\begin{array}{c}23003.573 \\
(23.786)\end{array}$ & $\begin{array}{c}24049.297 \\
(27.737)\end{array}$ & \\
\hline $45-49$ & $\begin{array}{c}10415.427 \\
(29.246)\end{array}$ & $\begin{array}{c}16064.461 \\
(27.856)\end{array}$ & $\begin{array}{c}21648.656 \\
(24.905)\end{array}$ & $\begin{array}{c}22578.212 \\
(23.132)\end{array}$ & $\begin{array}{c}25477.322 \\
(26.523)\end{array}$ & $\begin{array}{c}25884.023 \\
(41.110)\end{array}$ & \\
\hline $50-54$ & $\begin{array}{c}10757.581 \\
(27.400)\end{array}$ & $\begin{array}{c}18591.289 \\
(29.028)\end{array}$ & $\begin{array}{c}21768.123 \\
(25.522)\end{array}$ & $\begin{array}{c}24391.104 \\
(25.769)\end{array}$ & $\begin{array}{c}26026.161 \\
(28.150)\end{array}$ & & \\
\hline $55-59$ & $\begin{array}{c}11595.389 \\
(25.678)\end{array}$ & $\begin{array}{c}18502.732 \\
(26.155)\end{array}$ & $\begin{array}{c}21719.512 \\
(24.695)\end{array}$ & $\begin{array}{c}24945.432 \\
(26.019)\end{array}$ & $\begin{array}{c}25857.029 \\
(37.881)\end{array}$ & & \\
\hline $60-64$ & $\begin{array}{c}12504.368 \\
(21.183)\end{array}$ & $\begin{array}{c}16398.593 \\
(18.596)\end{array}$ & $\begin{array}{c}20786.203 \\
(20.299)\end{array}$ & $\begin{array}{c}23662.378 \\
(23.310)\end{array}$ & & & \\
\hline \multicolumn{8}{|c|}{ Number of children } \\
\hline & 1920-29 & 1930-39 & $1940-49$ & 1950-59 & 1960-69 & 1970-79 & 1980-89 \\
\hline $20-24$ & & & $\begin{array}{c}9631.613 \\
(22.722)\end{array}$ & $\begin{array}{c}10670.574 \\
(15.920)\end{array}$ & $\begin{array}{c}13830.608 \\
(17.134)\end{array}$ & $\begin{array}{c}13245.752 \\
(17.754)\end{array}$ & $\begin{array}{c}13539.685 \\
(23.554)\end{array}$ \\
\hline $25-29$ & & & $\begin{array}{c}10796.719 \\
(19.702)\end{array}$ & $\begin{array}{c}12509.090 \\
(17.670)\end{array}$ & $\begin{array}{c}17095.467 \\
(15.424)\end{array}$ & $\begin{array}{c}18430.285 \\
(19.707)\end{array}$ & $\begin{array}{c}19874.652 \\
(32.813)\end{array}$ \\
\hline $30-34$ & & $\begin{array}{c}10200.341 \\
(31.986)\end{array}$ & $\begin{array}{c}11806.616 \\
(21.163)\end{array}$ & $\begin{array}{c}16705.656 \\
(20.247)\end{array}$ & $\begin{array}{c}18964.672 \\
(18.322)\end{array}$ & $\begin{array}{c}22973.775 \\
(24.875)\end{array}$ & $\begin{array}{c}24233.418 \\
(40.128)\end{array}$ \\
\hline $35-39$ & & $\begin{array}{c}11006.131 \\
(26.828)\end{array}$ & $\begin{array}{c}15183.522 \\
(23.016)\end{array}$ & $\begin{array}{c}19791.366 \\
(20.883)\end{array}$ & $\begin{array}{c}22247.524 \\
(23.868)\end{array}$ & $\begin{array}{c}27153.251 \\
(30.802)\end{array}$ & $\begin{array}{c}26186.011 \\
(47.148)\end{array}$ \\
\hline $40-44$ & $\begin{array}{c}8816.758 \\
(31.451)\end{array}$ & $\begin{array}{c}12341.970 \\
(26.065)\end{array}$ & $\begin{array}{c}19253.144 \\
(24.436)\end{array}$ & $\begin{array}{c}21324.986 \\
(22.826)\end{array}$ & $\begin{array}{c}26404.265 \\
(29.489)\end{array}$ & $\begin{array}{c}29983.718 \\
(36.456)\end{array}$ & \\
\hline $45-49$ & $\begin{array}{c}8990.696 \\
(25.524)\end{array}$ & $\begin{array}{c}14266.155 \\
(25.418)\end{array}$ & $\begin{array}{c}20296.867 \\
(24.417)\end{array}$ & $\begin{array}{c}23206.138 \\
(25.646)\end{array}$ & $\begin{array}{c}28904.865 \\
(32.736)\end{array}$ & $\begin{array}{c}31695.255 \\
(52.894)\end{array}$ & \\
\hline $50-54$ & 9059.209 & 16050.925 & 19835.216 & 24432.590 & 28724.058 & & \\
\hline
\end{tabular}




\begin{tabular}{|c|c|c|c|c|c|c|c|}
\hline & $(23.428)$ & $(25.951)$ & $(24.619)$ & $(28.060)$ & $(33.652)$ & & \\
\hline $55-59$ & $\begin{array}{c}9563.318 \\
(21.618)\end{array}$ & $\begin{array}{c}15586.965 \\
(23.020)\end{array}$ & $\begin{array}{c}19361.988 \\
(23.829)\end{array}$ & $\begin{array}{c}24438.873 \\
(28.118)\end{array}$ & $\begin{array}{c}27645.326 \\
(42.722)\end{array}$ & & \\
\hline $60-64$ & $\begin{array}{c}10162.379 \\
(17.673)\end{array}$ & $\begin{array}{c}13595.856 \\
(16.453)\end{array}$ & $\begin{array}{c}18313.800 \\
(19.953)\end{array}$ & $\begin{array}{c}22876.700 \\
(25.287)\end{array}$ & & & \\
\hline \multicolumn{8}{|c|}{ Income transfers } \\
\hline & $1920-29$ & 1930-39 & $1940-49$ & $1950-59$ & $1960-69$ & $1970-79$ & $1980-89$ \\
\hline $20-24$ & & & $\begin{array}{c}9420.471 \\
(23.440)\end{array}$ & $\begin{array}{c}10479.231 \\
(17.600)\end{array}$ & $\begin{array}{c}13811.996 \\
(18.403)\end{array}$ & $\begin{array}{c}13500.491 \\
(18.220)\end{array}$ & $\begin{array}{c}13906.509 \\
(24.276)\end{array}$ \\
\hline $25-29$ & & & $\begin{array}{c}10516.737 \\
(20.979)\end{array}$ & $\begin{array}{c}12305.856 \\
(19.164)\end{array}$ & $\begin{array}{c}17122.527 \\
(15.579)\end{array}$ & $\begin{array}{c}18601.073 \\
(20.047)\end{array}$ & $\begin{array}{c}20038.121 \\
(33.180)\end{array}$ \\
\hline $30-34$ & & $\begin{array}{c}9496.771 \\
(31.297)\end{array}$ & $\begin{array}{c}11270.395 \\
(22.118)\end{array}$ & $\begin{array}{c}16081.389 \\
(20.559)\end{array}$ & $\begin{array}{c}18594.857 \\
(18.011)\end{array}$ & $\begin{array}{c}22541.962 \\
(24.343)\end{array}$ & $\begin{array}{c}23957.448 \\
(39.494)\end{array}$ \\
\hline $35-39$ & & $\begin{array}{c}10166.386 \\
(26.503)\end{array}$ & $\begin{array}{c}14349.792 \\
(23.845)\end{array}$ & $\begin{array}{c}18950.259 \\
(20.143)\end{array}$ & $\begin{array}{c}21353.369 \\
(22.464)\end{array}$ & $\begin{array}{c}26150.669 \\
(28.941)\end{array}$ & $\begin{array}{c}25759.843 \\
(46.040)\end{array}$ \\
\hline $40-44$ & $\begin{array}{c}8117.079 \\
(30.464)\end{array}$ & $\begin{array}{c}11544.542 \\
(26.128)\end{array}$ & $\begin{array}{c}18425.943 \\
(24.761)\end{array}$ & $\begin{array}{c}20542.066 \\
(21.804)\end{array}$ & $\begin{array}{c}25330.374 \\
(27.896)\end{array}$ & $\begin{array}{c}28957.637 \\
(34.131)\end{array}$ & \\
\hline $45-49$ & $\begin{array}{c}8561.622 \\
(25.567)\end{array}$ & $\begin{array}{c}13799.607 \\
(26.076)\end{array}$ & $\begin{array}{c}20022.977 \\
(24.189)\end{array}$ & $\begin{array}{c}22872.309 \\
(25.091)\end{array}$ & $\begin{array}{c}28296.509 \\
(31.412)\end{array}$ & $\begin{array}{c}31237.233 \\
(50.750)\end{array}$ & \\
\hline $50-54$ & $\begin{array}{c}8951.064 \\
(24.114)\end{array}$ & $\begin{array}{c}16193.789 \\
(26.462)\end{array}$ & $\begin{array}{c}20340.966 \\
(24.966)\end{array}$ & $\begin{array}{c}24918.942 \\
(27.901)\end{array}$ & $\begin{array}{c}29159.755 \\
(33.150)\end{array}$ & & \\
\hline $55-59$ & $\begin{array}{c}9865.510 \\
(22.442)\end{array}$ & $\begin{array}{c}16681.916 \\
(28.098)\end{array}$ & $\begin{array}{c}20794.705 \\
(28.917)\end{array}$ & $\begin{array}{c}25803.852 \\
(29.195)\end{array}$ & $\begin{array}{c}29088.859 \\
(44.001)\end{array}$ & & \\
\hline $60-64$ & $\begin{array}{c}11145.229 \\
(24.015) \\
\end{array}$ & $\begin{array}{c}15610.089 \\
(40.875) \\
\end{array}$ & $\begin{array}{c}20960.388 \\
(49.377) \\
\end{array}$ & $\begin{array}{c}25412.677 \\
(41.998) \\
\end{array}$ & & & \\
\hline \multicolumn{8}{|c|}{ Months of unemployment } \\
\hline & $1920-29$ & 1930-39 & 1940-49 & $1950-59$ & $1960-69$ & $1970-79$ & 1980-89 \\
\hline $20-24$ & & & $\begin{array}{c}9252.182 \\
(21.867)\end{array}$ & $\begin{array}{c}10309.260 \\
(15.422)\end{array}$ & $\begin{array}{c}13801.658 \\
(17.123)\end{array}$ & $\begin{array}{c}14116.844 \\
(18.680)\end{array}$ & $\begin{array}{c}13937.029 \\
(24.116)\end{array}$ \\
\hline $25-29$ & & & $\begin{array}{c}10378.266 \\
(19.106)\end{array}$ & $\begin{array}{c}12131.275 \\
(17.256)\end{array}$ & $\begin{array}{c}17679.691 \\
(15.528)\end{array}$ & $\begin{array}{c}19080.211 \\
(19.892)\end{array}$ & $\begin{array}{c}20363.097 \\
(33.031)\end{array}$ \\
\hline $30-34$ & & $\begin{array}{c}9361.515 \\
(29.720)\end{array}$ & $\begin{array}{c}11118.134 \\
(20.140)\end{array}$ & $\begin{array}{c}15981.370 \\
(19.452)\end{array}$ & $\begin{array}{c}19421.307 \\
(17.823)\end{array}$ & $\begin{array}{c}22879.575 \\
(23.987)\end{array}$ & $\begin{array}{c}24417.541 \\
(38.885)\end{array}$ \\
\hline $35-39$ & & $\begin{array}{c}10037.905 \\
(24.777)\end{array}$ & $\begin{array}{c}14134.438 \\
(21.556)\end{array}$ & $\begin{array}{c}19385.201 \\
(19.867)\end{array}$ & $\begin{array}{c}22023.199 \\
(22.100)\end{array}$ & $\begin{array}{c}26600.365 \\
(28.437)\end{array}$ & $\begin{array}{c}25528.365 \\
(44.301)\end{array}$ \\
\hline $40-44$ & $\begin{array}{c}8102.199 \\
(29.251)\end{array}$ & $\begin{array}{c}11364.584 \\
(24.253)\end{array}$ & $\begin{array}{c}18300.831 \\
(23.086)\end{array}$ & $\begin{array}{c}21327.556 \\
(21.541)\end{array}$ & $\begin{array}{c}25841.787 \\
(26.895)\end{array}$ & $\begin{array}{c}29202.329 \\
(33.298)\end{array}$ & \\
\hline $45-49$ & $\begin{array}{c}8478.180 \\
(24.308)\end{array}$ & $\begin{array}{c}13548.373 \\
(24.248)\end{array}$ & $\begin{array}{c}20335.591 \\
(23.796)\end{array}$ & $\begin{array}{c}23421.011 \\
(24.220)\end{array}$ & $\begin{array}{c}28767.435 \\
(30.409)\end{array}$ & $\begin{array}{c}30893.241 \\
(49.135)\end{array}$ & \\
\hline
\end{tabular}




\begin{tabular}{|c|c|c|c|c|c|c|c|}
\hline $50-54$ & $\begin{array}{c}8780.089 \\
(22.819)\end{array}$ & $\begin{array}{c}15966.497 \\
(25.706)\end{array}$ & $\begin{array}{c}20793.490 \\
(24.641)\end{array}$ & $\begin{array}{c}25198.217 \\
(27.221)\end{array}$ & $\begin{array}{c}29394.235 \\
(32.334)\end{array}$ & & \\
\hline $55-59$ & $\begin{array}{c}9510.452 \\
(21.519)\end{array}$ & $\begin{array}{c}16616.272 \\
(24.311)\end{array}$ & $\begin{array}{c}21195.354 \\
(24.735)\end{array}$ & $\begin{array}{c}26044.105 \\
(28.205)\end{array}$ & $\begin{array}{c}28986.215 \\
(42.663)\end{array}$ & & \\
\hline $60-64$ & $\begin{array}{c}10320.567 \\
(17.919)\end{array}$ & $\begin{array}{c}14635.794 \\
(17.494) \\
\end{array}$ & $\begin{array}{c}19888.911 \\
(20.495)\end{array}$ & $\begin{array}{c}24854.028 \\
(25.745)\end{array}$ & & & \\
\hline \multicolumn{8}{|c|}{ Age structure } \\
\hline & $1920-29$ & $1930-39$ & 1940-49 & $1950-59$ & $1960-69$ & 1970-79 & 1980-89 \\
\hline $20-24$ & & & $\begin{array}{c}10356.373 \\
(25.778)\end{array}$ & $\begin{array}{c}10545.500 \\
(16.221)\end{array}$ & $\begin{array}{c}13097.960 \\
(20.922)\end{array}$ & $\begin{array}{c}11162.428 \\
(33.607)\end{array}$ & $\begin{array}{c}10677.724 \\
(44.843)\end{array}$ \\
\hline $25-29$ & & & $\begin{array}{c}11617.318 \\
(24.218)\end{array}$ & $\begin{array}{c}12322.178 \\
(18.010)\end{array}$ & $\begin{array}{c}15958.349 \\
(21.287)\end{array}$ & $\begin{array}{c}15322.872 \\
(45.519)\end{array}$ & $\begin{array}{c}15353.049 \\
(63.937)\end{array}$ \\
\hline $30-34$ & & $\begin{array}{c}11852.195 \\
(48.841)\end{array}$ & $\begin{array}{c}12456.946 \\
(25.632)\end{array}$ & $\begin{array}{c}15944.797 \\
(20.179)\end{array}$ & $\begin{array}{c}17261.758 \\
(23.494)\end{array}$ & $\begin{array}{c}18504.829 \\
(55.019)\end{array}$ & $\begin{array}{c}18166.208 \\
(75.666)\end{array}$ \\
\hline $35-39$ & & $\begin{array}{c}12700.254 \\
(46.245)\end{array}$ & $\begin{array}{c}15805.597 \\
(28.623)\end{array}$ & $\begin{array}{c}18649.434 \\
(20.523)\end{array}$ & $\begin{array}{c}19979.923 \\
(28.630)\end{array}$ & $\begin{array}{c}21505.607 \\
(64.266)\end{array}$ & $\begin{array}{c}19475.524 \\
(82.156)\end{array}$ \\
\hline $40-44$ & $\begin{array}{c}10064.373 \\
(44.253)\end{array}$ & $\begin{array}{c}14379.761 \\
(48.556)\end{array}$ & $\begin{array}{c}20128.010 \\
(32.413)\end{array}$ & $\begin{array}{c}20213.796 \\
(22.318)\end{array}$ & $\begin{array}{c}23805.105 \\
(34.707)\end{array}$ & $\begin{array}{c}23873.703 \\
(71.318)\end{array}$ & \\
\hline $45-49$ & $\begin{array}{c}10485.075 \\
(39.765)\end{array}$ & $\begin{array}{c}17098.064 \\
(54.750)\end{array}$ & $\begin{array}{c}21649.504 \\
(34.140)\end{array}$ & $\begin{array}{c}22505.632 \\
(25.506)\end{array}$ & $\begin{array}{c}26571.651 \\
(39.148)\end{array}$ & $\begin{array}{c}26050.971 \\
(81.426)\end{array}$ & \\
\hline $50-54$ & $\begin{array}{c}10863.477 \\
(39.729)\end{array}$ & $\begin{array}{c}19775.960 \\
(61.677)\end{array}$ & $\begin{array}{c}21815.739 \\
(34.892)\end{array}$ & $\begin{array}{c}24431.696 \\
(28.582)\end{array}$ & $\begin{array}{c}27259.438 \\
(40.904)\end{array}$ & & \\
\hline $55-59$ & $\begin{array}{c}11743.282 \\
(40.611)\end{array}$ & $\begin{array}{c}19648.323 \\
(59.977)\end{array}$ & $\begin{array}{c}21812.572 \\
(34.507)\end{array}$ & $\begin{array}{c}25043.759 \\
(29.113)\end{array}$ & $\begin{array}{c}27085.651 \\
(48.706)\end{array}$ & & \\
\hline $60-64$ & $\begin{array}{c}12647.926 \\
(39.084)\end{array}$ & $\begin{array}{c}17415.727 \\
(51.211)\end{array}$ & $\begin{array}{c}20905.593 \\
(30.747)\end{array}$ & $\begin{array}{c}23767.579 \\
(26.272)\end{array}$ & & & \\
\hline \multicolumn{8}{|c|}{ Full model } \\
\hline & $1920-29$ & 1930-39 & $1940-49$ & $1950-59$ & $1960-69$ & $1970-79$ & $1980-89$ \\
\hline $20-24$ & & & $\begin{array}{c}10203.388 \\
(23.227)\end{array}$ & $\begin{array}{c}10107.253 \\
(14.493)\end{array}$ & $\begin{array}{c}12487.213 \\
(17.799)\end{array}$ & $\begin{array}{c}11560.319 \\
(28.712)\end{array}$ & $\begin{array}{c}10969.987 \\
(38.046)\end{array}$ \\
\hline $25-29$ & & & $\begin{array}{c}11385.628 \\
(21.012)\end{array}$ & $\begin{array}{c}11689.455 \\
(16.027)\end{array}$ & $\begin{array}{c}15932.512 \\
(18.222)\end{array}$ & $\begin{array}{c}14876.541 \\
(35.549)\end{array}$ & $\begin{array}{c}15096.110 \\
(51.182)\end{array}$ \\
\hline $30-34$ & & $\begin{array}{c}12354.595 \\
(43.299)\end{array}$ & $\begin{array}{c}12355.950 \\
(23.080)\end{array}$ & $\begin{array}{c}15832.602 \\
(18.721)\end{array}$ & $\begin{array}{c}17717.477 \\
(20.352)\end{array}$ & $\begin{array}{c}17925.050 \\
(42.808)\end{array}$ & $\begin{array}{c}18079.434 \\
(60.710)\end{array}$ \\
\hline $35-39$ & & $\begin{array}{c}13427.109 \\
(40.243)\end{array}$ & $\begin{array}{c}15848.263 \\
(26.067)\end{array}$ & $\begin{array}{c}19590.861 \\
(19.567)\end{array}$ & $\begin{array}{c}20029.244 \\
(24.181)\end{array}$ & $\begin{array}{c}20858.767 \\
(50.198)\end{array}$ & $\begin{array}{c}18576.885 \\
(63.407)\end{array}$ \\
\hline $40-44$ & $\begin{array}{c}11767.868 \\
(44.483)\end{array}$ & $\begin{array}{c}15105.878 \\
(42.298)\end{array}$ & $\begin{array}{c}20634.849 \\
(29.248)\end{array}$ & $\begin{array}{c}21330.707 \\
(20.359)\end{array}$ & $\begin{array}{c}23135.873 \\
(28.389)\end{array}$ & $\begin{array}{c}22554.724 \\
(53.935)\end{array}$ & \\
\hline
\end{tabular}




\begin{tabular}{lccccccc} 
45-49 & 12015.691 & 17585.990 & 22877.280 & 22777.210 & 25167.931 & 23512.466 & \\
& $(37.479)$ & $(46.521)$ & $(30.487)$ & $(21.732)$ & $(30.788)$ & $(58.794)$ & \\
$50-54$ & 12257.270 & 20450.753 & 22894.428 & 23838.184 & 24989.485 & & \\
& $(36.595)$ & $(52.460)$ & $(30.505)$ & $(23.589)$ & $(30.815)$ & & \\
$55-59$ & 13174.900 & 21351.644 & 22928.916 & 24187.861 & 24155.391 & & \\
& $(37.479)$ & $(53.722)$ & $(31.265)$ & $(24.167)$ & $(37.084)$ & & \\
$60-64$ & 14432.840 & 18896.664 & 21517.258 & 22999.523 & & & \\
& $(37.904)$ & $(49.211)$ & $(33.846)$ & $(25.783)$ & & & \\
\hline $\mathrm{N}$ & 12429152 & 12429152 & 12429152 & 12429152 & 12429152 & 12429152 & 12429152 \\
\hline $\mathrm{Stanyyyy}$
\end{tabular}

Standard errors in parentheses

Note: All estimates statistically significant, $p<0.001$ 
Table A.5. Relative change of income according to ten years interval categories and overall average change over age- and cohort groups, repeated-measures linear regression implementing the method of generalized estimation equations (GEE), two-way cohort $\mathrm{X}$ age interaction effects for men's income.

Empty model

\begin{tabular}{|c|c|c|c|c|c|c|c|c|}
\hline & $1920-29$ & 1930-39 & $1940-49$ & $1950-59$ & $1960-69$ & $1970-79$ & $1980-89$ & Average change \\
\hline $20-24$ & & & ref & $-5 \%$ & $28 \%$ & $-4 \%$ & $5 \%$ & $6 \%$ \\
\hline $25-29$ & & & ref & $-2 \%$ & $12 \%$ & $15 \%$ & $2 \%$ & $7 \%$ \\
\hline $30-34$ & & & ref & $9 \%$ & $2 \%$ & $28 \%$ & $-1 \%$ & $9 \%$ \\
\hline $35-39$ & & ref & $13 \%$ & $6 \%$ & $12 \%$ & $21 \%$ & $-2 \%$ & $10 \%$ \\
\hline $40-44$ & ref & $24 \%$ & $23 \%$ & $-5 \%$ & $25 \%$ & $14 \%$ & & $16 \%$ \\
\hline $45-49$ & ref & $16 \%$ & $18 \%$ & $6 \%$ & $21 \%$ & $14 \%$ & & $15 \%$ \\
\hline $50-54$ & ref & $31 \%$ & $5 \%$ & $16 \%$ & $15 \%$ & & & $17 \%$ \\
\hline $55-59$ & ref & $30 \%$ & $14 \%$ & $16 \%$ & $13 \%$ & & & $18 \%$ \\
\hline \multirow[t]{4}{*}{$60-64$} & ref & $20 \%$ & $27 \%$ & $12 \%$ & & & & $20 \%$ \\
\hline & \multicolumn{7}{|c|}{ Average all ages and cohorts } & $13 \%$ \\
\hline & \multicolumn{8}{|c|}{ Goldthorpe-Erikson-Portocarero (EGP) class scheme } \\
\hline & $1920-29$ & 1930-39 & $1940-49$ & $1950-59$ & $1960-69$ & $1970-79$ & $1980-89$ & Average change \\
\hline $20-24$ & & & ref & $-5 \%$ & $25 \%$ & $-4 \%$ & $7 \%$ & $6 \%$ \\
\hline $25-29$ & & & ref & $-2 \%$ & $13 \%$ & $15 \%$ & $3 \%$ & $7 \%$ \\
\hline $30-34$ & & & ref & $10 \%$ & $2 \%$ & $25 \%$ & $0 \%$ & $9 \%$ \\
\hline $35-39$ & & ref & $6 \%$ & $8 \%$ & $12 \%$ & $18 \%$ & $-4 \%$ & $8 \%$ \\
\hline $40-44$ & ref & $14 \%$ & $18 \%$ & $-4 \%$ & $24 \%$ & $10 \%$ & & $12 \%$ \\
\hline $45-49$ & ref & $8 \%$ & $15 \%$ & $6 \%$ & $20 \%$ & $9 \%$ & & $11 \%$ \\
\hline $50-54$ & ref & $23 \%$ & $2 \%$ & $16 \%$ & $12 \%$ & & & $14 \%$ \\
\hline $55-59$ & ref & $24 \%$ & $10 \%$ & $16 \%$ & $10 \%$ & & & $15 \%$ \\
\hline \multirow[t]{4}{*}{$60-64$} & ref & $14 \%$ & $23 \%$ & $11 \%$ & & & & $16 \%$ \\
\hline & \multirow{2}{*}{\multicolumn{7}{|c|}{ Average all ages and cohorts }} & $11 \%$ \\
\hline & & & & & & & & \\
\hline & 1920-29 & 1930-39 & 1940-49 & $1950-59$ & 1960-69 & 1970-79 & 1980-89 & \\
\hline $20-24$ & & & ref & $-9 \%$ & $21 \%$ & $-7 \%$ & $7 \%$ & $3 \%$ \\
\hline $25-29$ & & & ref & $-7 \%$ & $6 \%$ & $9 \%$ & $2 \%$ & $2 \%$ \\
\hline $30-34$ & & & ref & $3 \%$ & $-4 \%$ & $20 \%$ & $-2 \%$ & $4 \%$ \\
\hline $35-39$ & & ref & $7 \%$ & $0 \%$ & $6 \%$ & $13 \%$ & $-3 \%$ & $5 \%$ \\
\hline $40-44$ & ref & $19 \%$ & $17 \%$ & $-11 \%$ & $18 \%$ & $7 \%$ & & $10 \%$ \\
\hline $45-49$ & ref & $12 \%$ & $12 \%$ & $-1 \%$ & $13 \%$ & $7 \%$ & & $9 \%$ \\
\hline $50-54$ & ref & $27 \%$ & $0 \%$ & $9 \%$ & $8 \%$ & & & $11 \%$ \\
\hline $55-59$ & ref & $26 \%$ & $8 \%$ & $8 \%$ & $6 \%$ & & & $12 \%$ \\
\hline $60-64$ & ref & $16 \%$ & $21 \%$ & $5 \%$ & & & & $14 \%$ \\
\hline
\end{tabular}


Number of children

\begin{tabular}{|c|c|c|c|c|c|c|c|c|}
\hline & $1920-29$ & 1930-39 & $1940-49$ & $1950-59$ & $1960-69$ & $1970-79$ & $1980-89$ & \\
\hline $20-24$ & & & ref & $-5 \%$ & $29 \%$ & $-3 \%$ & $6 \%$ & $7 \%$ \\
\hline $25-29$ & & & ref & $-2 \%$ & $12 \%$ & $16 \%$ & $2 \%$ & $7 \%$ \\
\hline $30-34$ & & & ref & $9 \%$ & $2 \%$ & $28 \%$ & $-1 \%$ & $9 \%$ \\
\hline $35-39$ & & ref & $14 \%$ & $6 \%$ & $13 \%$ & $21 \%$ & $-1 \%$ & $11 \%$ \\
\hline $40-44$ & ref & $25 \%$ & $24 \%$ & $-6 \%$ & $25 \%$ & $15 \%$ & & $17 \%$ \\
\hline $45-49$ & ref & $17 \%$ & $18 \%$ & $6 \%$ & $21 \%$ & $15 \%$ & & $15 \%$ \\
\hline $50-54$ & ref & $31 \%$ & $6 \%$ & $16 \%$ & $15 \%$ & & & $17 \%$ \\
\hline $55-59$ & ref & $30 \%$ & $14 \%$ & $16 \%$ & $13 \%$ & & & $18 \%$ \\
\hline \multirow[t]{4}{*}{ 60-64 } & ref & $20 \%$ & $28 \%$ & $12 \%$ & & & & $20 \%$ \\
\hline & \multirow{2}{*}{\multicolumn{7}{|c|}{$\begin{array}{l}\text { Average all ages and cohorts } \\
\text { Income transfers }\end{array}$}} & $13 \%$ \\
\hline & \multicolumn{5}{|c|}{ Income transfers } & & & \\
\hline & $1920-29$ & 1930-39 & $1940-49$ & $1950-59$ & $1960-69$ & 1970-79 & $1980-89$ & \\
\hline $20-24$ & & & ref & $-5 \%$ & $28 \%$ & $-4 \%$ & $5 \%$ & $6 \%$ \\
\hline $25-29$ & & & ref & $-2 \%$ & $13 \%$ & $15 \%$ & $2 \%$ & $7 \%$ \\
\hline $30-34$ & & & ref & $9 \%$ & $2 \%$ & $27 \%$ & $-1 \%$ & $9 \%$ \\
\hline $35-39$ & & ref & $13 \%$ & $7 \%$ & $12 \%$ & $21 \%$ & $-2 \%$ & $10 \%$ \\
\hline $40-44$ & ref & $24 \%$ & $24 \%$ & $-5 \%$ & $25 \%$ & $14 \%$ & & $16 \%$ \\
\hline $45-49$ & ref & $17 \%$ & $19 \%$ & $5 \%$ & $21 \%$ & $15 \%$ & & $15 \%$ \\
\hline 50-54 & ref & $32 \%$ & $6 \%$ & $15 \%$ & $15 \%$ & & & $17 \%$ \\
\hline $55-59$ & ref & $32 \%$ & $13 \%$ & $15 \%$ & $13 \%$ & & & $18 \%$ \\
\hline \multirow[t]{4}{*}{ 60-64 } & ref & $22 \%$ & $26 \%$ & $10 \%$ & & & & $20 \%$ \\
\hline & \multicolumn{8}{|c|}{ Average all ages and cohorts } \\
\hline & \multicolumn{8}{|c|}{ Months of unemployment } \\
\hline & 1920-29 & $1930-39$ & $1940-49$ & $1950-59$ & $1960-69$ & $1970-79$ & $1980-89$ & Average change \\
\hline $20-24$ & & & ref & $-4 \%$ & $34 \%$ & $3 \%$ & $-2 \%$ & $8 \%$ \\
\hline $25-29$ & & & ref & $-1 \%$ & $25 \%$ & $11 \%$ & $2 \%$ & $9 \%$ \\
\hline 30-34 & & & ref & $13 \%$ & $10 \%$ & $22 \%$ & $1 \%$ & $11 \%$ \\
\hline $35-39$ & & ref & $14 \%$ & $15 \%$ & $11 \%$ & $20 \%$ & $-4 \%$ & $11 \%$ \\
\hline $40-44$ & ref & $24 \%$ & $28 \%$ & $1 \%$ & $22 \%$ & $14 \%$ & & $18 \%$ \\
\hline $45-49$ & ref & $17 \%$ & $27 \%$ & $6 \%$ & $21 \%$ & $10 \%$ & & $16 \%$ \\
\hline $50-54$ & ref & $35 \%$ & $12 \%$ & $15 \%$ & $15 \%$ & & & $19 \%$ \\
\hline $55-59$ & ref & $41 \%$ & $16 \%$ & $14 \%$ & $11 \%$ & & & $20 \%$ \\
\hline \multirow[t]{4}{*}{ 60-64 } & ref & $27 \%$ & $30 \%$ & $13 \%$ & & & & $23 \%$ \\
\hline & \multirow{2}{*}{\multicolumn{8}{|c|}{$\begin{array}{l}\text { Average all ages and cohorts } \\
\text { Age structure }\end{array}$}} \\
\hline & & & & & & & & \\
\hline & 1920-29 & $1930-39$ & $1940-49$ & $1950-59$ & $1960-69$ & $1970-79$ & $1980-89$ & Average change \\
\hline $20-24$ & & & ref & $-13 \%$ & $20 \%$ & $-15 \%$ & $-2 \%$ & $-3 \%$ \\
\hline $25-29$ & & & ref & $-11 \%$ & $6 \%$ & $1 \%$ & $-5 \%$ & $-2 \%$ \\
\hline $30-34$ & & & ref & $-2 \%$ & $-4 \%$ & $12 \%$ & $-8 \%$ & $0 \%$ \\
\hline
\end{tabular}




\begin{tabular}{|c|c|c|c|c|c|c|c|c|}
\hline $35-39$ & & ref & $-2 \%$ & $-4 \%$ & $6 \%$ & $6 \%$ & $-8 \%$ & $0 \%$ \\
\hline $40-44$ & ref & $19 \%$ & $7 \%$ & $-15 \%$ & $18 \%$ & $1 \%$ & & $6 \%$ \\
\hline $45-49$ & ref & $11 \%$ & $2 \%$ & $-5 \%$ & $14 \%$ & $2 \%$ & & $5 \%$ \\
\hline $50-54$ & ref & $25 \%$ & $-8 \%$ & $5 \%$ & $8 \%$ & & & $8 \%$ \\
\hline $55-59$ & ref & $25 \%$ & $-1 \%$ & $4 \%$ & $7 \%$ & & & $9 \%$ \\
\hline \multirow[t]{3}{*}{$60-64$} & ref & $15 \%$ & $11 \%$ & $1 \%$ & & & & $9 \%$ \\
\hline & \multicolumn{8}{|c|}{$\begin{array}{l}\text { Average all ages and cohorts } \\
\text { Full model }\end{array}$} \\
\hline & 1920-29 & 1930-39 & 1940-49 & $1950-59$ & 1960-69 & $1970-79$ & 1980-89 & Average change \\
\hline $20-24$ & & & ref & $-14 \%$ & $24 \%$ & $-8 \%$ & $-4 \%$ & $0 \%$ \\
\hline $25-29$ & & & ref & $-12 \%$ & $16 \%$ & $-3 \%$ & $-2 \%$ & $0 \%$ \\
\hline $30-34$ & & & ref & $1 \%$ & $3 \%$ & $5 \%$ & $-4 \%$ & $1 \%$ \\
\hline $35-39$ & & ref & $-5 \%$ & $5 \%$ & $2 \%$ & $3 \%$ & $-10 \%$ & $-1 \%$ \\
\hline $40-44$ & ref & $11 \%$ & $8 \%$ & $-9 \%$ & $11 \%$ & $-3 \%$ & & $4 \%$ \\
\hline $45-49$ & ref & $5 \%$ & $9 \%$ & $-6 \%$ & $11 \%$ & $-6 \%$ & & $3 \%$ \\
\hline $50-54$ & ref & $23 \%$ & $-4 \%$ & $2 \%$ & $5 \%$ & & & $6 \%$ \\
\hline $55-59$ & ref & $30 \%$ & $-2 \%$ & $1 \%$ & $0 \%$ & & & $8 \%$ \\
\hline \multirow[t]{2}{*}{$60-64$} & ref & $17 \%$ & $9 \%$ & $0 \%$ & & & & $9 \%$ \\
\hline & & & & & 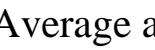 & $x$ & ohorts & $3 \%$ \\
\hline
\end{tabular}


Table A.6. Relative change of income according to ten years interval categories and overall average change over age- and cohort groups, repeated-measures linear regression implementing the method of generalized estimation equations (GEE), two-way cohort $\mathrm{X}$ age interaction effects for women's income.

\begin{tabular}{|c|c|c|c|c|c|c|c|c|}
\hline & \multicolumn{8}{|c|}{ Empty model } \\
\hline & 1920-29 & 1930-39 & 1940-49 & $1950-59$ & $1960-69$ & 1970-79 & $1980-89$ & Average change \\
\hline $20-24$ & & & Ref. & $11 \%$ & $30 \%$ & $-3 \%$ & $3 \%$ & $10 \%$ \\
\hline $25-29$ & & & Ref. & $16 \%$ & $36 \%$ & $9 \%$ & $8 \%$ & $17 \%$ \\
\hline $30-34$ & & Ref. & $18 \%$ & $41 \%$ & $14 \%$ & $22 \%$ & $6 \%$ & $20 \%$ \\
\hline $35-39$ & & Ref. & $40 \%$ & $30 \%$ & $12 \%$ & $22 \%$ & $-2 \%$ & $20 \%$ \\
\hline $40-44$ & Ref. & $41 \%$ & $58 \%$ & $10 \%$ & $24 \%$ & $14 \%$ & & $29 \%$ \\
\hline $45-49$ & Ref. & $60 \%$ & $43 \%$ & $14 \%$ & $24 \%$ & $10 \%$ & & $30 \%$ \\
\hline $50-54$ & Ref. & $78 \%$ & $24 \%$ & $23 \%$ & $17 \%$ & & & $36 \%$ \\
\hline $55-59$ & Ref. & $64 \%$ & $25 \%$ & $26 \%$ & $13 \%$ & & & $32 \%$ \\
\hline \multirow[t]{4}{*}{$60-64$} & Ref. & $35 \%$ & $35 \%$ & $25 \%$ & & & & $32 \%$ \\
\hline & \multicolumn{7}{|c|}{ Average all ages and cohorts } & $25 \%$ \\
\hline & \multicolumn{8}{|c|}{ Goldthorpe-Erikson-Portocarero (EGP) class scheme } \\
\hline & $1920-29$ & 1930-39 & $1940-49$ & $1950-59$ & $1960-69$ & 1970-79 & $1980-89$ & Average change \\
\hline $20-24$ & & & Ref. & $8 \%$ & $29 \%$ & $-3 \%$ & $5 \%$ & $10 \%$ \\
\hline $25-29$ & & & Ref. & $12 \%$ & $36 \%$ & $8 \%$ & $8 \%$ & $16 \%$ \\
\hline $30-34$ & & Ref. & $9 \%$ & $37 \%$ & $13 \%$ & $19 \%$ & $5 \%$ & $17 \%$ \\
\hline $35-39$ & & Ref. & $29 \%$ & $29 \%$ & $10 \%$ & $19 \%$ & $-5 \%$ & $16 \%$ \\
\hline $40-44$ & Ref. & $29 \%$ & $48 \%$ & $8 \%$ & $20 \%$ & $10 \%$ & & $23 \%$ \\
\hline $45-49$ & Ref. & $46 \%$ & $36 \%$ & $10 \%$ & $21 \%$ & $5 \%$ & & $24 \%$ \\
\hline $50-54$ & Ref. & $63 \%$ & $18 \%$ & $18 \%$ & $13 \%$ & & & $28 \%$ \\
\hline $55-59$ & Ref. & $51 \%$ & $16 \%$ & $22 \%$ & $9 \%$ & & & $24 \%$ \\
\hline \multirow[t]{4}{*}{$60-64$} & Ref. & $23 \%$ & $25 \%$ & $20 \%$ & & & & $23 \%$ \\
\hline & \multicolumn{8}{|c|}{ Average all ages and cohorts } \\
\hline & \multicolumn{8}{|c|}{ Education } \\
\hline & 1920-29 & 1930-39 & $1940-49$ & $1950-59$ & $1960-69$ & 1970-79 & $1980-89$ & Average change \\
\hline $20-24$ & & & Ref. & $5 \%$ & $22 \%$ & $-8 \%$ & $5 \%$ & $6 \%$ \\
\hline $25-29$ & & & Ref. & $8 \%$ & $26 \%$ & $1 \%$ & $6 \%$ & $10 \%$ \\
\hline $30-34$ & & Ref. & $12 \%$ & $31 \%$ & $4 \%$ & $12 \%$ & $4 \%$ & $12 \%$ \\
\hline $35-39$ & & Ref. & $32 \%$ & $20 \%$ & $2 \%$ & $12 \%$ & $-4 \%$ & $13 \%$ \\
\hline $40-44$ & Ref. & $36 \%$ & $49 \%$ & $1 \%$ & $12 \%$ & $5 \%$ & & $21 \%$ \\
\hline $45-49$ & Ref. & $54 \%$ & $35 \%$ & $4 \%$ & $13 \%$ & $2 \%$ & & $22 \%$ \\
\hline $50-54$ & Ref. & $73 \%$ & $17 \%$ & $12 \%$ & $7 \%$ & & & $27 \%$ \\
\hline $55-59$ & Ref. & $60 \%$ & $17 \%$ & $15 \%$ & $4 \%$ & & & $24 \%$ \\
\hline $60-64$ & Ref. & $31 \%$ & $27 \%$ & $14 \%$ & & & & $24 \%$ \\
\hline & & & & & Average a & 11 ages ar & cohorts & $18 \%$ \\
\hline & & & & Numb & er of chi & Iren & & \\
\hline
\end{tabular}


1920-29 1930-39 $\quad 1940-49 \quad 1950-59 \quad 1960-69 \quad 1970-79 \quad 1980-89$ Average change

\begin{tabular}{|c|c|c|c|c|c|c|c|c|}
\hline $20-24$ & & & Ref. & $11 \%$ & $30 \%$ & $-4 \%$ & $2 \%$ & $10 \%$ \\
\hline $25-29$ & & & Ref. & $16 \%$ & $37 \%$ & $8 \%$ & $8 \%$ & $17 \%$ \\
\hline $30-34$ & & Ref. & $16 \%$ & $41 \%$ & $14 \%$ & $21 \%$ & $5 \%$ & $19 \%$ \\
\hline $35-39$ & & Ref. & $38 \%$ & $30 \%$ & $12 \%$ & $22 \%$ & $-4 \%$ & $20 \%$ \\
\hline $40-44$ & Ref. & $40 \%$ & $56 \%$ & $11 \%$ & $24 \%$ & $14 \%$ & & $29 \%$ \\
\hline $45-49$ & Ref. & $59 \%$ & $42 \%$ & $14 \%$ & $25 \%$ & $10 \%$ & & $30 \%$ \\
\hline $50-54$ & Ref. & $77 \%$ & $24 \%$ & $23 \%$ & $18 \%$ & & & $35 \%$ \\
\hline $55-59$ & Ref. & $63 \%$ & $24 \%$ & $26 \%$ & $13 \%$ & & & $32 \%$ \\
\hline \multirow[t]{4}{*}{$60-64$} & Ref. & $34 \%$ & $35 \%$ & $25 \%$ & & & & $31 \%$ \\
\hline & & & & Ince & $\begin{array}{l}\text { Average a } \\
\text { me transfe }\end{array}$ & $\begin{array}{l}11 \text { ages an } \\
\text { ers }\end{array}$ & d cohorts & $25 \%$ \\
\hline & 1920-29 & 1930-39 & 1940-49 & $1950-59$ & $1960-69$ & 1970-79 & $1980-89$ & Average change \\
\hline & $1920-$ & 1930- & 1940- & $1950-$ & 1960- & 1970- & 1980- & \\
\hline $20-24$ & & & Ref. & $11 \%$ & $32 \%$ & $-2 \%$ & $3 \%$ & $11 \%$ \\
\hline $25-29$ & & & Ref. & $17 \%$ & $39 \%$ & $9 \%$ & $8 \%$ & $18 \%$ \\
\hline $30-34$ & & Ref. & $19 \%$ & $43 \%$ & $16 \%$ & $21 \%$ & $6 \%$ & $21 \%$ \\
\hline $35-39$ & & Ref. & $41 \%$ & $32 \%$ & $13 \%$ & $22 \%$ & $-1 \%$ & $21 \%$ \\
\hline $40-44$ & Ref. & $42 \%$ & $60 \%$ & $11 \%$ & $23 \%$ & $14 \%$ & & $30 \%$ \\
\hline $45-49$ & Ref. & $61 \%$ & $45 \%$ & $14 \%$ & $24 \%$ & $10 \%$ & & $31 \%$ \\
\hline $50-54$ & Ref. & $81 \%$ & $26 \%$ & $23 \%$ & $17 \%$ & & & $37 \%$ \\
\hline $55-59$ & Ref. & $69 \%$ & $25 \%$ & $24 \%$ & $13 \%$ & & & $33 \%$ \\
\hline $60-64$ & Ref. & $40 \%$ & $34 \%$ & $21 \%$ & & & & $32 \%$ \\
\hline
\end{tabular}

Average all ages and cohorts $26 \%$

Age structure

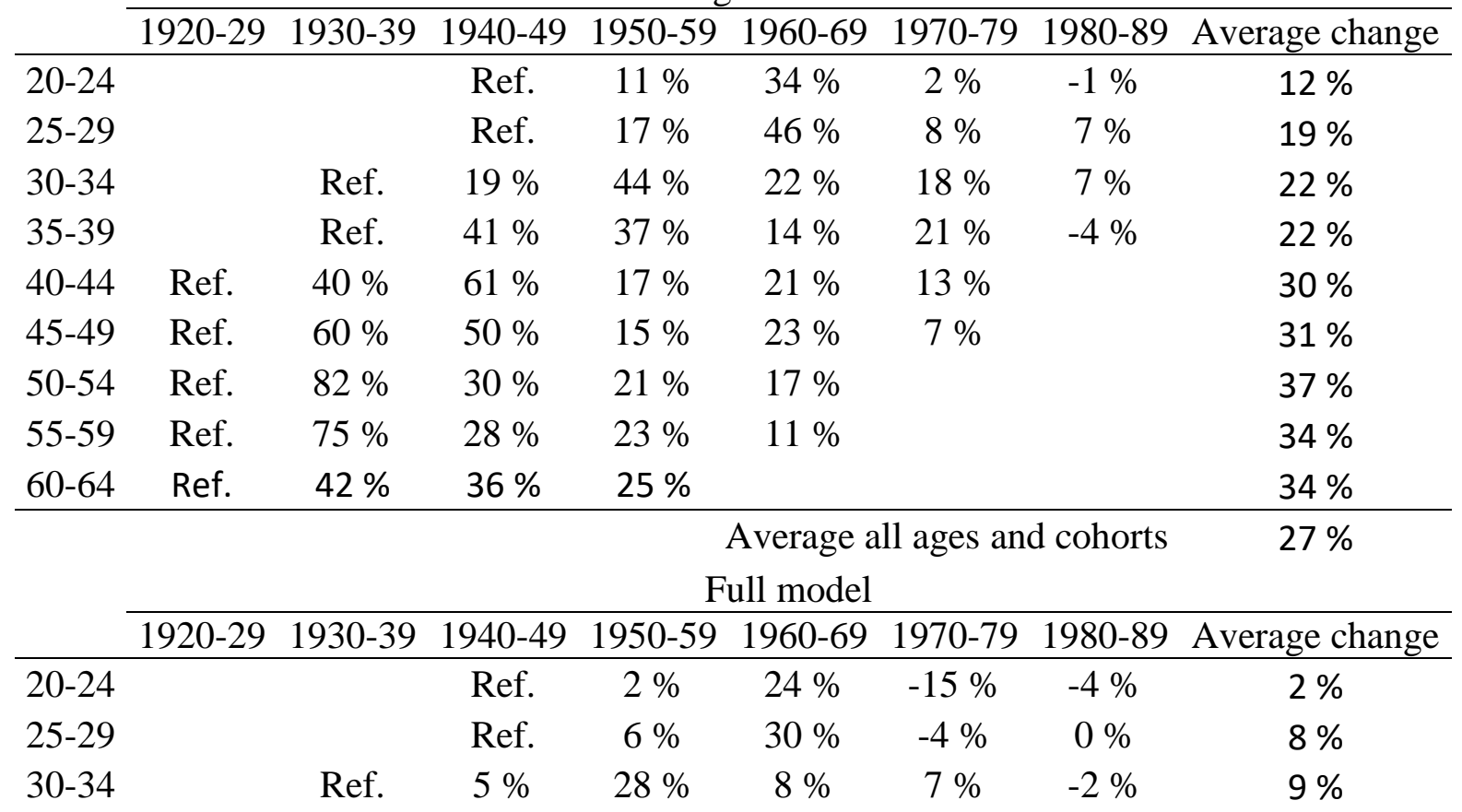




\begin{tabular}{|c|c|c|c|c|c|c|c|c|}
\hline $35-39$ & & Ref. & $24 \%$ & $18 \%$ & $7 \%$ & $8 \%$ & $-9 \%$ & $10 \%$ \\
\hline $40-44$ & Ref. & $43 \%$ & $40 \%$ & $0 \%$ & $18 \%$ & $0 \%$ & & $20 \%$ \\
\hline $45-49$ & Ref. & $63 \%$ & $27 \%$ & $4 \%$ & $18 \%$ & $-2 \%$ & & $22 \%$ \\
\hline $50-54$ & Ref. & $82 \%$ & $10 \%$ & $12 \%$ & $12 \%$ & & & $29 \%$ \\
\hline $55-59$ & Ref. & $67 \%$ & $11 \%$ & $15 \%$ & $8 \%$ & & & $25 \%$ \\
\hline \multirow[t]{4}{*}{$60-64$} & Ref. & $38 \%$ & $20 \%$ & $14 \%$ & & & & $24 \%$ \\
\hline & \multirow{2}{*}{\multicolumn{8}{|c|}{$\begin{array}{l}\text { Average all ages and cohorts } \\
\text { Empty model }\end{array}$}} \\
\hline & & & & & & & & \\
\hline & 1920-29 & 1930-39 & $1940-49$ & 1950-59 & 1960-69 & $1970-79$ & 1980-89 & Average change \\
\hline $20-24$ & & & Ref. & $-1 \%$ & $24 \%$ & $-7 \%$ & $-5 \%$ & $3 \%$ \\
\hline $25-29$ & & & Ref. & $3 \%$ & $36 \%$ & $-7 \%$ & $1 \%$ & $8 \%$ \\
\hline $30-34$ & & Ref. & $0 \%$ & $28 \%$ & $12 \%$ & $1 \%$ & $1 \%$ & $8 \%$ \\
\hline $35-39$ & & Ref. & $18 \%$ & $24 \%$ & $2 \%$ & $4 \%$ & $-11 \%$ & $7 \%$ \\
\hline $40-44$ & Ref. & $28 \%$ & $37 \%$ & $3 \%$ & $8 \%$ & $-3 \%$ & & $15 \%$ \\
\hline $45-49$ & Ref. & $46 \%$ & $30 \%$ & $0 \%$ & $10 \%$ & $-7 \%$ & & $16 \%$ \\
\hline $50-54$ & Ref. & $67 \%$ & $12 \%$ & $4 \%$ & $5 \%$ & & & $22 \%$ \\
\hline $55-59$ & Ref. & $62 \%$ & $7 \%$ & $5 \%$ & $0 \%$ & & & $19 \%$ \\
\hline \multirow[t]{2}{*}{$60-64$} & Ref. & $31 \%$ & $14 \%$ & $7 \%$ & & & & $17 \%$ \\
\hline & & & & & verag & ages & cohorts & $13 \%$ \\
\hline
\end{tabular}


Table A.7. Cohort variances for men over individual birth cohorts according to the age groups.

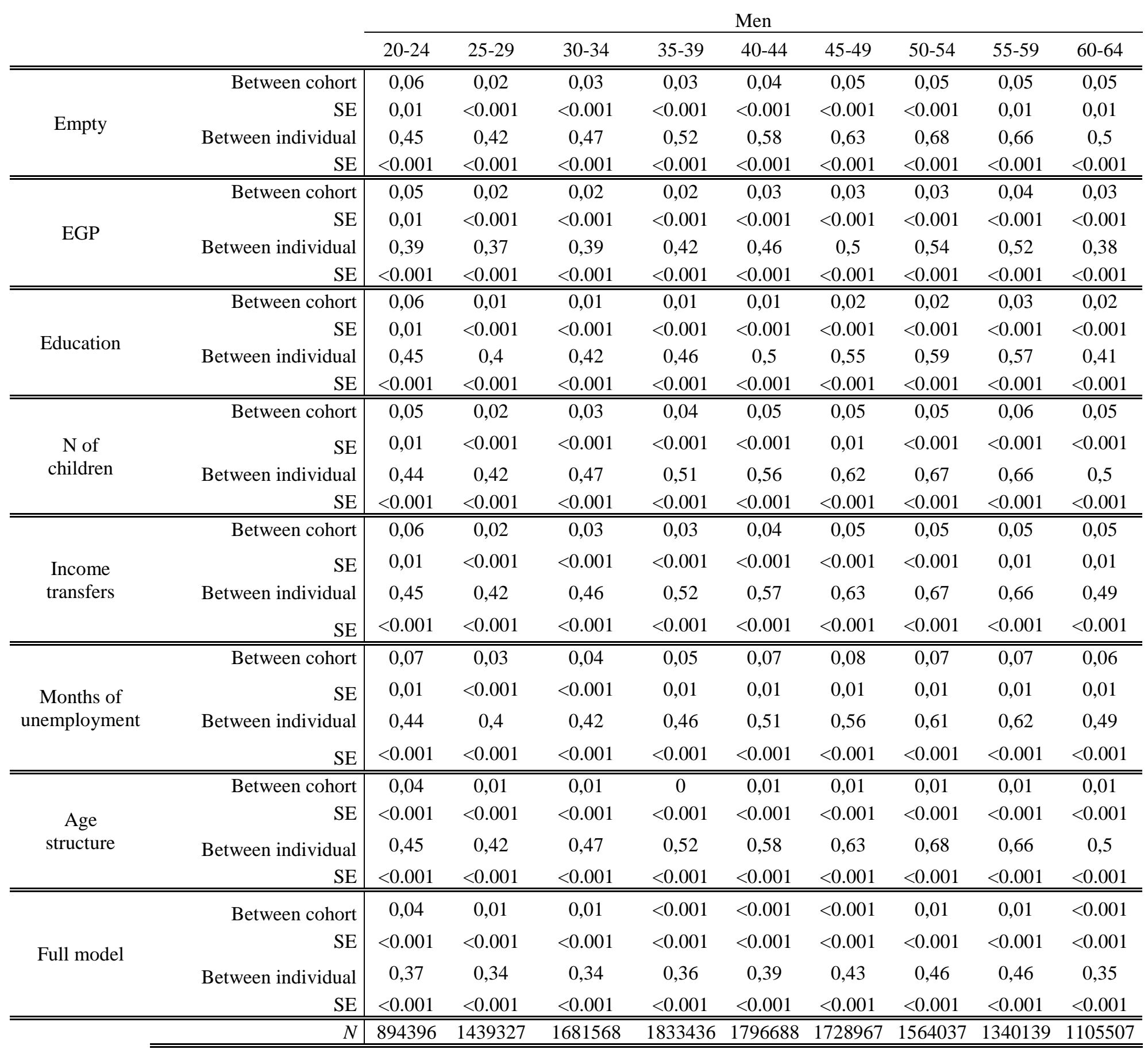


Table A.8. Cohort variances for women over individual birth cohorts according to the age groups.

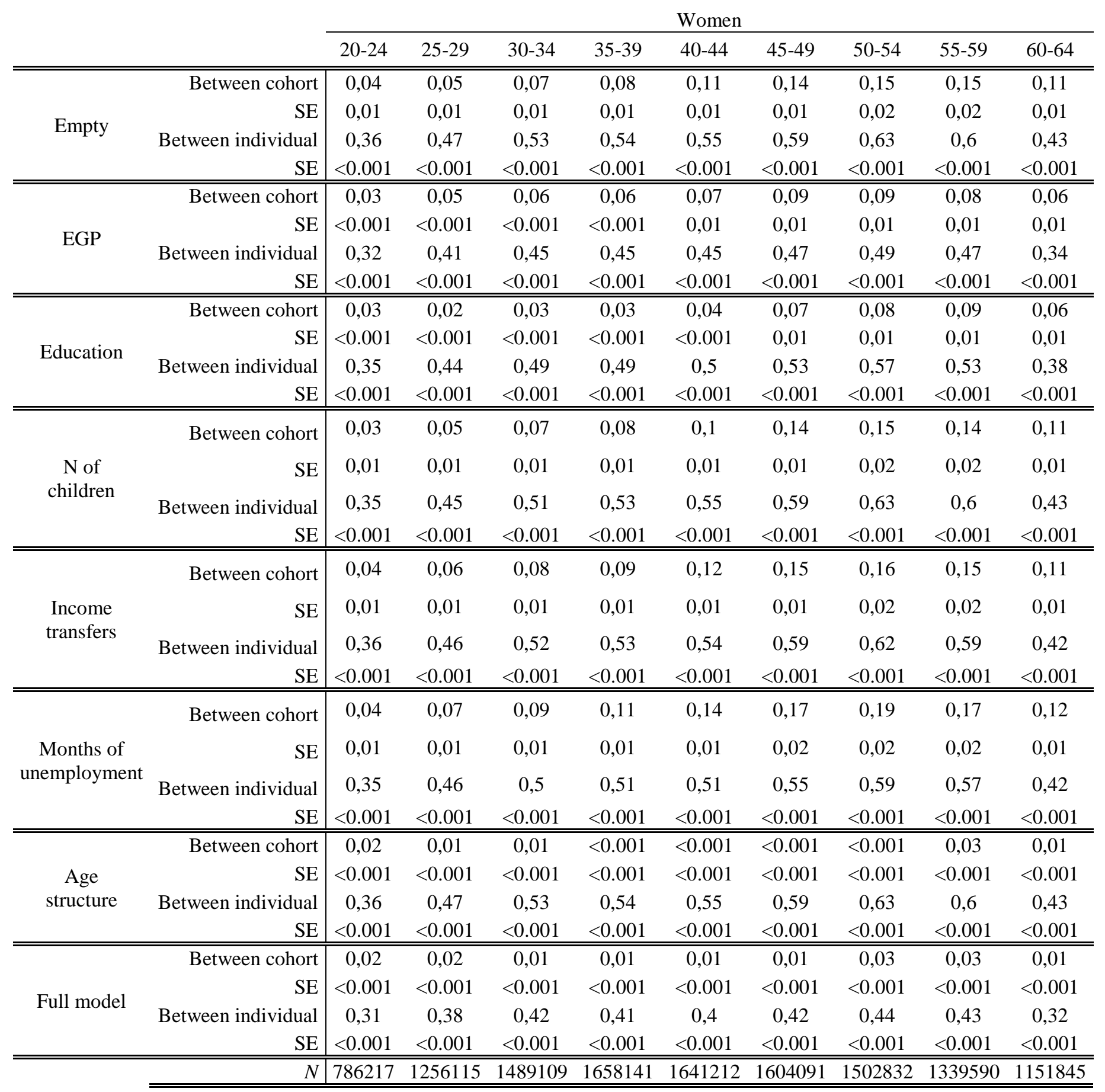




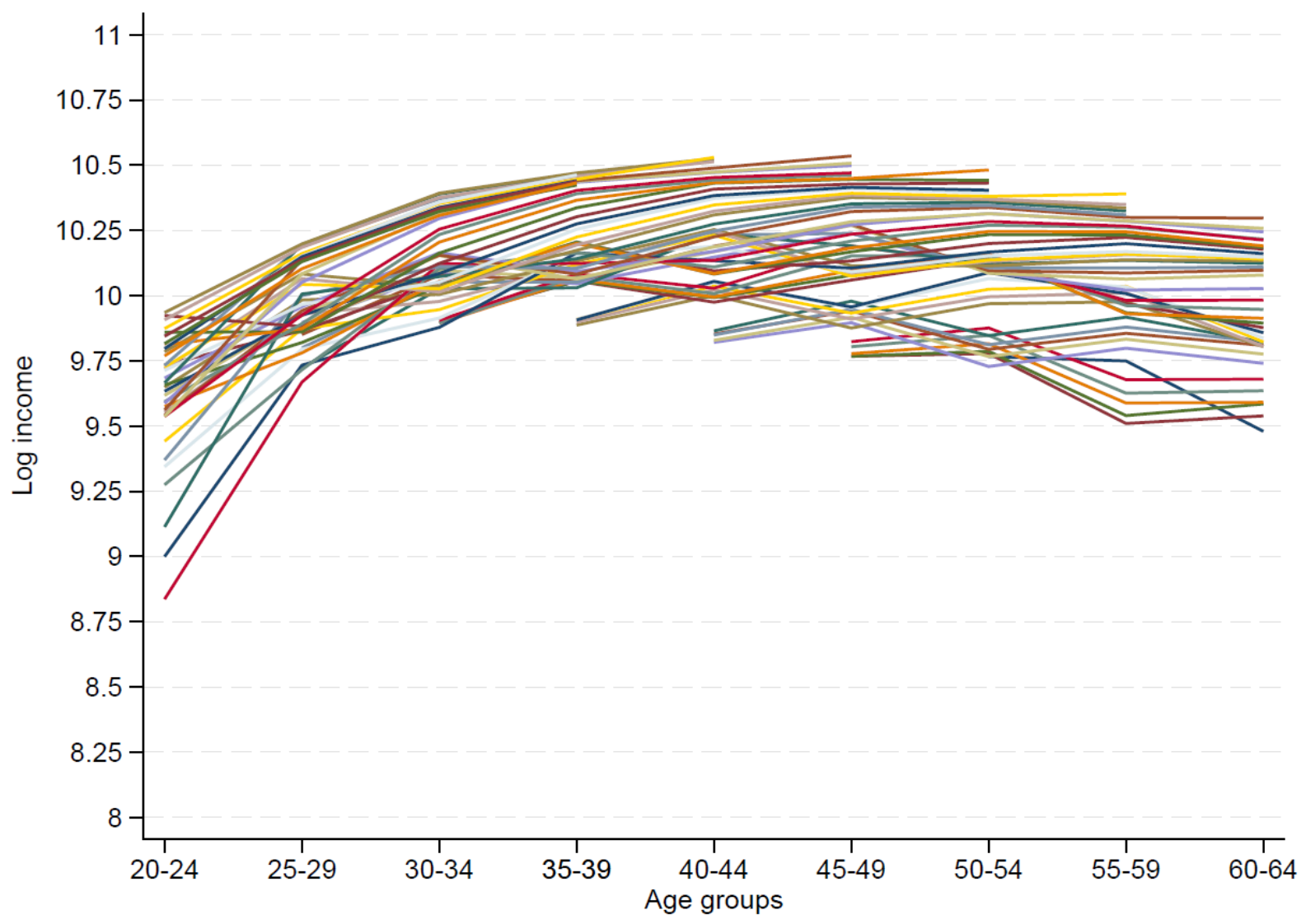

Figure A.9. Average income trajectories of each individual birth cohorts (1920s-1980s) in log income during 1970-2018, men. 


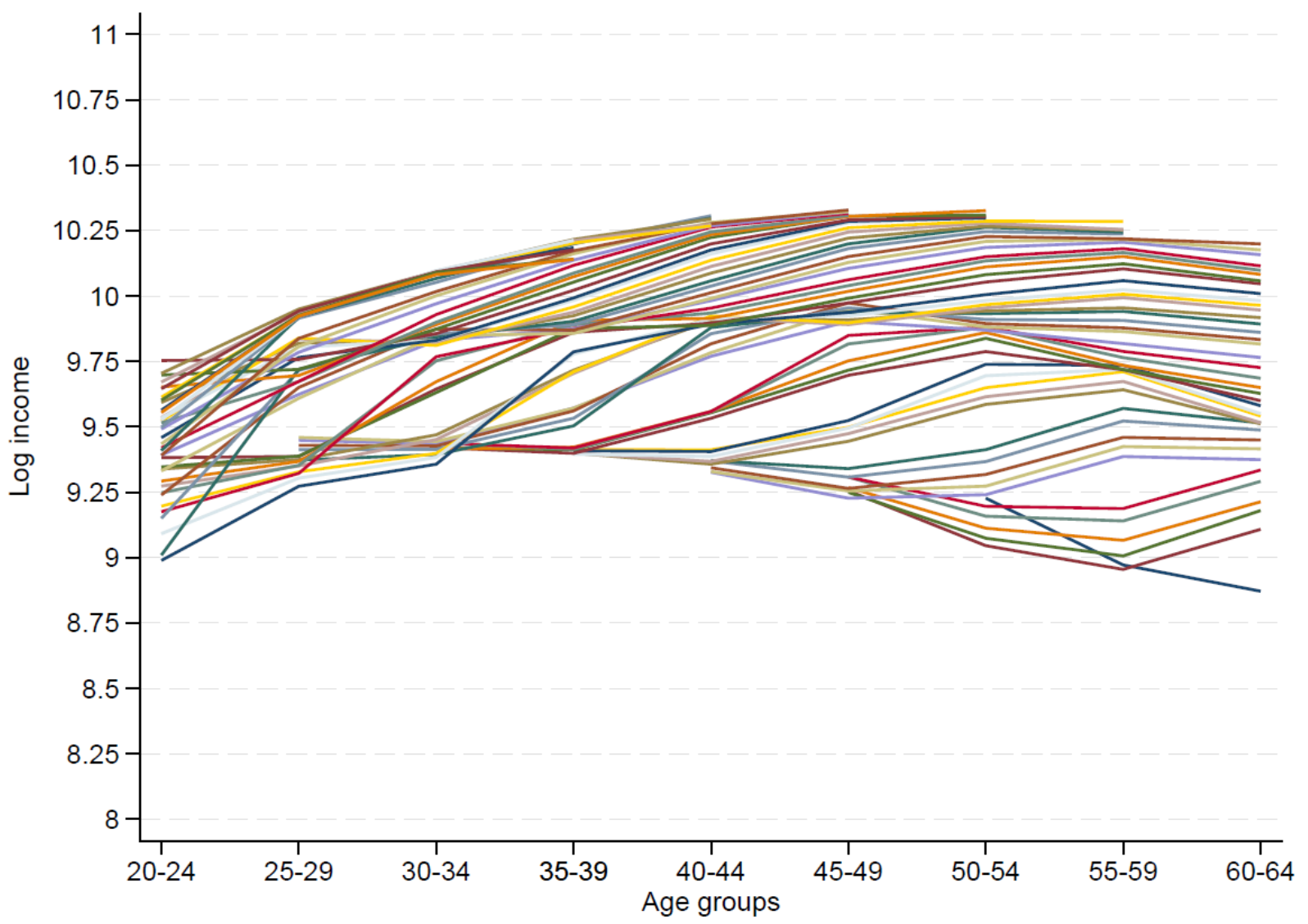

Figure A.10. Average income trajectories of each individual birth cohorts (1920s-1980s) in log income during 1970-2018, women. 


\section{References}

Alestalo M. (2007). Rakennemuutokset ja sukupolvet. http://www.julkari.fi/handle/10024/101070

Antikainen A., Kauppila J. (2002). Educational generations and the futures of adult education: a Nordic experience. International Journal of Lifelong Education, 21(3), 209-219. https://doi.org/10.1080/02601370210127828

Atkinson A. B. (2015). Inequality: What Can Be Done? Cambridge, Massachusetts: Harvard University Press.

Batini N., Callegari G., Guerreiro J. (2011). An Analysis of US Fiscal and Generational Imbalances: Who Will Pay and How? Washington, D. C.: International Monetary Fund.

Becker G. (1962). Investment in human capital: a theoretical analysis. Journal of Political Economy, 70. https://econpapers.repec.org/article/ucpjpolec/v_3a70_3ay_3a1962_3ap_3a9.htm

Becker G. S. (2009). Human Capital: A Theoretical and Empirical Analysis, with Special Reference to Education. Chicago: University of Chicago Press.

Berloffa G., Villa P. (2010). Differences in equivalent income across cohorts of households: evidence from Italy. Review of Income and Wealth, 56(4), 693-714. https://doi.org/10.1111/j.1475-4991.2010.00403.x

Bol T. (2015). Has education become more positional? Educational expansion and labour market outcomes, 1985-2007. Acta Sociologica, 58(2), 105-120. https://doi.org/10.1177/0001699315570918

Bongaarts J., Sobotka, T. (2012). A demographic explanation for the recent rise in European fertility. Population and Development Review, 38(1), 83-120. 
Breen R., Luijkx R., Müller W., Pollak R. (2009). Nonpersistent inequality in educational attainment: evidence from eight European countries. American Journal of Sociology, 114(5), 1475-1521. https://doi.org/10.1086/595951

Breen R., Luijkx R., Müller W., Pollak R. (2010). Long-term trends in educational inequality in Europe: class inequalities and gender differences. European Sociological Review, 26(1), $31-48$.

Breen, R. (2018). Social mobility in Europe. In Social Stratification. Routledge, 464-479. https://doi.org/10.1093/esr/jcp001

Budig M. J., Misra J., Boeckmann I. (2012). The motherhood penalty in cross-national perspective: the importance of work-family policies and cultural attitudes. Social Politics: International Studies in Gender, State \& Society, 19(2), 163-193. https://doi.org/10.1093/sp/jxs006

Chauvel L., Schroder M. (2014). Generational inequalities and welfare regimes. Social Forces, 92(4), 1259-1283. https://doi.org/10.1093/sf/sot156

Chetty R., Grusky D., Hell M., Hendren N., Manduca R., Narang J. (2017). The fading American dream: trends in absolute income mobility since 1940. Science, 356(6336), 398-406.

Crawford R., Innes D., O’Dea C. (2016, March 31). Household wealth in Great Britain: distribution, composition and changes 2006-12. Fiscal Studies, 37(1). https://doi.org/10.1111/j.1475-5890.2016.12083

Mannheim, K. (1928). Das Problem der Generationen. Kölner Vierteljahreshefte für Soziologie, 7, 157-185, 309-330.

Erikson R., Goldthorpe J. H. (2002). Intergenerational inequality: a sociological perspective. The Journal of Economic Perspectives, 16(3), 31-44. http://www.jstor.org/stable/3216948 
Esping-Andersen G. (1990). The Three Worlds of Welfare Capitalism. Princeton: Princeton University Press.

Freund D., Smeeding T. M. (2010). The future costs of health care in ageing societies: Is the glass half full or half empty? In XX X. (Ed.), Ageing in Advanced Industrial States. City: Springer, pp. 173-193.

Gangl M., Ziefle A. (2009). Motherhood, labor force behavior, and women's careers: an empirical assessment of the wage penalty for motherhood in Britain, Germany, and the United States. Demography, 46(2), 341-369. https://doi.org/10.1353/dem.0.0056

Halaby C. N. (1994). Overeducation and skill mismatch. Sociology of Education, 67(1), 47-59. https://doi.org/10.2307/2112749

Härkönen J., Bihagen E. (2011). Occupational attainment and career progression in Sweden. European Societies, 13(3), 451-479. https://doi.org/10.1080/14616696.2011.568261

Härkönen J., Sirniö O. (2020). Educational transitions and educational inequality: a multiple pathways sequential logit model analysis of Finnish birth cohorts 1960-1985. European Sociological Review, 36(5), 700-719.

Harmon C., Walker I., Westergærd-Nielsen N. C. (2001). Education and Earnings in Europe: A Cross Country Analysis of the Returns to Education. City: Edward Elgar Publishing.

Iversen T., Soskice D. (2009). Distribution and redistribution: the shadow of the nineteenth century. World Politics, 61(3), 438-486.

Jalovaara M., Neyer G., Andersson G., Dahlberg J., Dommermuth L., Fallesen P., Lappegård T. (2019). Education, gender, and cohort fertility in the Nordic countries. European Journal of Population, 35(3), 563-586. 
Kangas O. E., Ritakallio V.-M. (2007). Relative to what?: cross-national picture of European poverty measured by regional, national and European standards. European Societies, 9(2), 119-145.

Kangas O., Palme J. (2000). Does social policy matter? Poverty cycles in OECD countries. International Journal of Health Services, 30(2), 335-352.

Karisto A. (2007). Finnish baby boomers and the emergence of the third age. International Journal of Ageing and Later Life, 2(2), 91-108. https://doi.org/10.3384/ijal.16528670.072291

Karonen E., Niemelä M. (2020). Life course perspective on economic shocks and income inequality through age-period-cohort analysis: evidence from Finland. Review of Income and Wealth, 66(2), 287-310. https://doi.org/10.1111/roiw.12409

Karonen E., Niemelä M., \& Erola J. (2017). The Middle Class in Finland. In XX X. (Ed.), No Robots: The Position of Middle-Class Households in Nine European Countries. City: Publisher.

Korpi W., Palme J. (1998). The paradox of redistribution and strategies of equality: welfare state institutions, inequality, and poverty in the Western countries. American Sociological Review, X, 661-687.

Lehti H., Karonen E. (2020). Educational expansion and returns to university education between various fields of studies in Finland during the 1990s and the 2000s. Sosiologia, 2, 130147.

Mayer K. U. (2000). Promises fulfilled? A review of 20 years of life course research. European Journal of Sociology, 41(02), 259-282. http://journals.cambridge.org/abstract_S0003975600007049 
Mayer K. U. (2009). New directions in life course research. Annual Review of Sociology, 35(1), 413-433. https://doi.org/10.1146/annurev.soc.34.040507.134619

Mincer J. (1970). The distribution of labor incomes: a survey with special reference to the human capital approach. Journal of Economic Literature, 8(1), 1-26. https://www.jstor.org/stable/2720384

Mugiyama R., Toyonaga K. (2021). Role of cohort size in trends in class and occupational returns to education at first job: the case of Japan. European Sociological Review. https://doi.org/10.1093/esr/jcab037

Myles J. (2002). A New Social Contract for the Elderly? In XX X. (Ed.), Why We Need a New Welfare State. Oxford: Oxford University Press. https://doi.org/10.1093/0199256438.003.0005

Myrskylä M., Goldstein J. R., Cheng Y. A. (2013). New cohort fertility forecasts for the developed world: rises, falls, and reversals. Population and Development Review, 39(1), 31-56.

Myrskylä M., Kohler H.-P., Billari F. C. (2009). Advances in development reverse fertility declines. Nature, 460(7256), 741-743.

Möhring, K. (2016). Life course regimes in Europe: Individual employment histories in comparative and historical perspective. Journal of European Social Policy, 26(2), 124139. https://doi.org/10.1177/0958928716633046

OECD. (2019). Education at a Glance 2019 OECD Indicators. Paris: OECD.

Pekkala S., Lucas R. E. B. (2007). Differences across cohorts in Finnish intergenerational income mobility. Industrial Relations: A Journal of Economy and Society, 46(1), 81-111. https://doi.org/10.1111/j.1468-232X.2007.00458.x 
Pekkarinen T., Uusitalo R., Pekkala Kerr S. (2009). School tracking and intergenerational income mobility: evidence from the Finnish comprehensive school reform. Journal of Public Economics, 93(7-8), 965-973. https://econpapers.repec.org/article/eeepubeco/v_3a93_3ay_3a2009_3ai_3a78_3ap_3a965-973.htm

Riihelä M. (2006, March 21). Kotitalouksien kulutus ja säästäminen: Ikäprofiilien ja kohorttien kuvaus. Valtion taloudellinen tutkimuskeskus VATT. https://www.doria.fi/handle/10024/148366

Schofer E., Meyer J. W. (2005). The worldwide expansion of higher education in the twentieth century. American Sociological Review, 70(6), 898-920. https://doi.org/10.1177/000312240507000602

Sieppi A., Pehkonen J. (2019). Parenthood and gender inequality: population-based evidence on the child penalty in Finland. Economics Letters, 182, 5-9. https://doi.org/10.1016/j.econlet.2019.05.034

Statistics Finland (2000). Population Census 2000, Handbooks 35c. Helsinki.

Suoniemi I. (2012). Income mobility, income risk and age - Finnish experiences in 1995-2008. In Working Papers (No. 276; Working Papers). Palkansaajien tutkimuslaitos, Labour Institute for Economic Research. https://ideas.repec.org/p/pst/wpaper/276.html

Tepe M., Vanhuysse P. (2009). Are aging OECD welfare states on the path to gerontocracy?: evidence from 18 democracies, 1980-2002. Journal of Public Policy, 29(1), 1-28. https://doi.org/10.1017/S0143814X0900097X 
Thévenon O., Luci A. (2010). Macro perspective on fertility trends and institutional context. Report to the European Commission within the Project "Reproductive Decision-Making in a Macro-Micro Perspective”. Springer, Dordrecht, The Netherlands, 1-15.

Timonen V., Kautto M. (2014). Sustaining the Nordic welfare model in the face of population ageing. International Handbook on Ageing and Public Policy. Edward Elgar Publishing.

Twisk J. W. R. (2004). Longitudinal Data Analysis. A Comparison Between Generalized Estimating Equations and Random Coefficient Analysis. European Journal of Epidemiology, 19(8), 769-776. https://doi.org/10.1023/B:EJEP.0000036572.00663.f2

Van de Werfhorst H. G., Andersen R. (2005). Social background, credential inflation and educational strategies. Acta Sociologica, 48(4), 321-340.

Van Winkle Z., Fasang A. (2017). Complexity in employment life courses in Europe in the twentieth century_large cross-national differences but little change across birth cohorts. Social Forces, 96(1), 1-30. https://doi.org/10.1093/sf/sox032 